\title{
DO MARKET LEADERS LEAD IN BUSINESS PROCESS INNOVATION? THE CASE(S) OF E-BUSINESS ADOPTION
}

by

\author{
Kristina Steffenson McElheran * \\ Harvard Business School
}

\section{CES 11-10 April, 2011}

The research program of the Center for Economic Studies (CES) produces a wide range of economic analyses to improve the statistical programs of the U.S. Census Bureau. Many of these analyses take the form of CES research papers. The papers have not undergone the review accorded Census Bureau publications and no endorsement should be inferred. Any opinions and conclusions expressed herein are those of the author(s) and do not necessarily represent the views of the U.S. Census Bureau. All results have been reviewed to ensure that no confidential information is disclosed. Republication in whole or part must be cleared with the authors.

To obtain information about the series, see www.census.gov/ces or contact Cheryl Grim, Editor, Discussion Papers, U.S. Census Bureau, Center for Economic Studies 2K130B, 4600 Silver Hill Road, Washington, DC 20233, CES.Papers.List@census.gov. 


\begin{abstract}
This paper investigates the relationship between market position and the adoption of IT-enabled process innovations. Prior research has focused overwhelmingly on product innovation and garnered mixed empirical support. I extend the literature into the understudied area of business process innovation, developing a framework for classifying innovations based on the complexity, interdependence, and customer impact of the underlying business process. I test the framework's predictions in the context of ebuying and e-selling adoption. Leveraging detailed U.S. Census data, I find robust evidence that market leaders were significantly more likely to adopt the incremental innovation of e-buying but commensurately less likely to adopt the more radical practice of e-selling. The findings highlight the strategic significance of adjustment costs and co-invention capabilities in technology adoption, particularly as businesses grow more dependent on new technologies for their operational and competitive performance.
\end{abstract}

* Many thanks are due to Shane Greenstein, Scott Stern, Rebecca Henderson, Alfonso Gambardella, Steve Kahl, Juan Alcacer, Andrew King, participants of the Colloquium on Competition and Competitiveness, and numerous others I met while on the job market. I am indebted to T. Lynn Riggs and other members of the Center for Economic Studies for their support. Any opinions and conclusions expressed herein are those of the author and do not necessarily represent the views of the U.S. Census Bureau. All results have been reviewed to ensure that no confidential information is disclosed. Support for this research at the Chicago RDC from NSF (awards no. SES-0004335 and ITR-0427889) is also gratefully acknowledged. In addition, I am thankful for financial support from the Census Bureau's Dissertation Fellowship program and the State Farm Companies Foundation Dissertation Award. All errors remain my own. 


\section{Introduction}

The adoption of new technologies is central to how firms compete, grow, and change over time. Since the pioneering work of Joseph Schumpeter $(1934,1942)$, scholars have explored why certain innovations are adopted quickly by market leaders while others are ignored or absorbed only slowly. A principal tradition in the literature points to the need for a match between the nature of the technological change and the attributes of the firm. This work proposes that new technologies can be misaligned with a firm's technological or market competencies, hindering adoption. If misalignment is more prevalent amongst larger incumbents, this would explain the observed failure of healthy firms to maintain their technological - and potentially, competitive - advantage over time. This, in turn, has deep implications for market structure and firm strategy in the face of technological change.

A useful framework for considering the alignment between technological requirements and organizational capabilities focuses on the extent to which an innovation is "incremental" or "radical" for an adopting firm. According to this perspective, incremental change that reinforces the strategic and organizational advantages of incumbents ought to be more readily adopted by market leaders. Larger incumbents enjoy greater incentives (due in part to economies of scale) as well as greater ability (due to better-established routines, knowledge, and capabilities) to succeed at incremental innovation. In contrast, radical changes that threaten existing strategic positions and demand entirely new knowledge and capabilities ought to be less attractive and accessible to leading incumbents. Specifically, the very organizational features that are associated with market success also tend to generate higher adjustment costs and greater economic and organizational risks for large incumbents adopting radical innovations.

A large theoretical literature in both economics and strategy has leveraged this contrast between incremental and radical innovation to explore leading firms' responses to innovative opportunities. Yet, empirical evidence remains mixed. While support for the incremental-radical distinction has been found in some small, single-industry studies, large-scale, multi-industry evidence has been harder to acquire.

In addition, the scope of the theory remains unclear. Both theoretical and empirical innovation research has focused overwhelmingly on product innovation, with some attention to manufacturing processes. The extent to which these constructs apply to business process innovation has not been fully explored to date-despite the growing importance of this activity in the modern economy.

The goal of this paper is to make both theoretical and empirical headway by examining how market leadership influences firm propensity to adopt new IT-enabled business process innovations. The theoretical contribution centers on extending hypotheses of incremental versus radical innovation into the important but understudied context of business process innovation. I develop a framework for classifying innovations as "incremental" or "radical" based on: 1) the underlying complexity of the business process to be affected, 2) its interdependence with other firm activities, and 3) its impact on customers. 
Combining this framework with arguments from existing research, I motivate two core predictions. Large incumbents ought to excel at so-defined incremental business process innovation, but they will face disproportionate challenges in pursuing radical changes. I integrate this framework with a detailed qualitative analysis of two new IT-enabled business process innovations - e-buying and e-selling - to establish a theoretically and intuitively sound basis for the empirical tests to follow.

The empirical contribution comes from leveraging a unique data set with several desirable properties. The first is broad industry coverage. The data come from a U.S. Census Bureau survey of over 35,000 plants in 86 different manufacturing industries. This offers a window onto IT-enabled process innovation amongst an unusually comprehensive sample of firms. Secondly, the setting captures reactions of the same firms at the same time to both incremental and radical innovations. I can thus directly compare leaders' reactions to the two types of business process innovation, highlighting the incrementalradical distinction while controlling for unobserved influences on the investment decision. In addition, the richness of the data permits robust controls for other important firm and industry characteristics. Finally, the data also capture elusive organizational features that relate to the underlying theory, allowing me to test not only the main predictions but also supporting conjectures about the precise behavioral mechanisms involved.

A side-by-side comparison of the adoption of e-buying and e-selling during the early diffusion of the commercial internet constitutes my primary test of the theory. While both shared many technological requirements and imposed changes in business-to-business operations, they diverged dramatically along the dimensions outlined in the framework. E-buying entailed the electronic procurement of highly standardized materials such as office and maintenance supplies that, while impacting the cost structure of the firm, posed limited economic and organizational risks for adopters. E-selling, by contrast, governed a far greater complexity of products, interacted with core functions such as marketing and customer management, and generated significant customer resistance and channel conflict. Mapping these differences onto the framework provides a compelling argument that e-buying represented incremental change, while e-selling embodied the central elements of a radical business process innovation.

I find strong evidence consistent with this framework and its attendant hypotheses. In this large and diverse sample of manufacturers, those with the greatest market shares, sales, and profits were significantly more likely to adopt e-buying, with the opposing result in the case of e-selling. These findings are robust to various alternative explanations that are also testable with the rich Census data.

Understanding when leading firms will fail to embrace new technologies is critical to understanding the evolution of industrial competition. Much of our current appreciation for the competitive implications of innovation centers on the behavior of firms that produce new technologies. However, an important process of adaptation and complementary innovation - or "co-invention" - takes 
places when firms adopt new general purpose technologies - including, but not limited to, modern information technology. Thus, it becomes essential to consider whether firms might be able to gain or retain competitive advantages by leveraging technology to innovate in their internal processes - and whether the capabilities to do so reside predominantly among market leaders or smaller rivals.

This paper contributes to our understanding in this area by providing robust, multi-industry evidence consistent with the notion that alignment (or lack thereof) between the requirements of a technology and a firm's organizational capabilities can explain why large firms readily adopt and adapt certain technologies and not others. In addition, it gleans this evidence from a class of innovative behavior that is both understudied in the literature and increasingly important in today's high-tech economy. Finally, it develops a theoretical framework that: 1) establishes links between existing theory and this novel context and 2) carefully outlines the behavioral mechanism in a way that deepens our understanding of the phenomenon and enables corroborating empirical testing.

These findings have important practical implications. Being able to apply our intuition about the innovative behavior of firms requires the means to distinguish, ex ante, whether a proposed change lies on the incremental or radical end of the spectrum. The theory and evidence presented in this paper indicate that, in cases where firms must coordinate complex and interdependent activities throughout a larger organization - particularly while interacting with customers - adoption will tend to take place among smaller firms. This intra- and inter-firm coordination challenge is an important strategic consideration as businesses grow more dependent on both new technology and the performance of their supply chain partners. As this technology advances, leading firms may face increasing challenges from smaller rivals who better exploit internal and business-to-business process innovation to their competitive advantage.

\section{Literature and Theoretical Context}

\subsection{Overview}

A rich body of work in both economic and organizational theory addresses the question of how incumbent firms with large market shares will react to -and participate in -technological change. While the inquiry dates back at least to Schumpeter (1934, 1942), Arrow's seminal (1962) theory that existing monopolists will resist innovating so as to avoid cannibalizing existing sales sparked a surge of research into the effects of market structure and firm size on innovative activity (see reviews by Kamien and Schwartz 1982, Baldwin and Scott 1987, and Gilbert 2006, among others).

Economic research in this vein emphasizes the strategic benefits to market leaders of maintaining their dominant position in the face of technological change. Because a large firm with market power will enjoy higher rents per unit of sales, it will have greater marginal incentive to protect that power. Thus, market leaders will, in many circumstances, be more likely to invest in technology that allows them to 
lower costs and price more aggressively in the product market (Sutton 1991) or to otherwise pre-empt entry in the first place (Gilbert and Newbery 1982). ${ }^{1}$

In the specific case of process innovation, economic theory suggests that basic economies of scale will increase the benefits of innovation for larger firms relative to smaller ones (Cohen and Klepper 1996, Klepper 1996). Barring any adjustment costs that might also increase disproportionately with firm size (Athey and Schmutzler 2001), market leaders will enjoy higher net benefits from process innovation.

Yet the adjustment costs associated with adopting new technologies are often not trivial. The history of industrial evolution is littered with firms that were unable to maintain their leadership position in the wake of technological change. A principal explanation is that, even in situations where they enjoy greater incentive to innovate, leaders may vary in their ability to embrace new innovative opportunities (Henderson 1993, Arora et al. 2009). In particular, the alignment between the incentives and abilities of leading firms is argued to vary systematically according to characteristics of the innovations themselves.

\subsection{Incremental vs. Radical Innovation}

According to a rich organizational theory literature, leaders will excel at adopting innovations that build upon their existing knowledge and capabilities. Labeling this category of innovation is delicate, because: 1) innovative activity lies on a multi-dimensional spectrum, 2) a wide range of labels address these important dimensions, and 3) significant ambiguity in definitions persists (Gatignon et al. 2002). Nevertheless, for over 35 years, the most accessible type of innovative activity has often been described as "incremental" (e.g., Nelson and Winter 1982 through to Gatignon, et al. 2002), capturing the essential idea that certain types of innovation entail lower economic and/or organizational risks for adopting firms.

Much of the organizational theory literature argues that firms tend to develop routines (Nelson and Winter 1982) and information filters (Arrow 1974) based on prior experience that embody organizational knowledge and condition how they react to changes in their environments. As a result, greater experience gained over a larger scale of activity and/or over time will make it easier for larger incumbents to identify and pursue innovations that build on existing knowledge and competencies (Abernathy and Clark 1985, Tushman and Anderson 1986). Larger firms may also have invested more in resources (Wernerfelt 1984), capabilities (Barney 1991) or complementary assets (Tripsas 1997) that enable them to effectively exploit incremental advances. Thus, leading firms will often be not only more willing, but also more able to pursue incremental innovations than their smaller, less-established rivals.

On the other end of the spectrum are "radical" innovations. Again, this term is more convenient than encompassing given a variety of ways to characterize the misalignment between a technology's requirements and an organization's ability to meet them. Typically, radical innovations require

\footnotetext{
${ }^{1}$ Athey and Schmutzler (2001) develop a very general model that predicts leading firms will be more likely to invest under a wide range of common modeling assumptions.
} 
dramatically new knowledge on the part of the adopting firm (Dewar and Dutton 1986, Gatignon et al. 2002) or accelerate the obsolescence of the existing knowledge base (Reinganum 1983). They may demand entirely new competencies from firms to operate and exploit the new technology (Tushman and Anderson 1986). A critical consideration is how changes to the linkages amongst product attributes (Henderson and Clark 1990) or between the firm and its customer base (Abernathy and Clark 1985) can demand new ways of processing information and communicating both within and between firms.

The literature on radical innovation emphasizes that, while these innovations are often more challenging for all incumbents, they may, under many circumstances, be disproportionately more difficult for the largest organizations. To begin, larger firms may have lower incentives to invest if the new innovation replaces existing revenue streams (Arrow 1962). These "economically radical" (Henderson 1993) innovations thus present higher opportunity costs to leaders (although the ultimate impact depends on market entry and the degree of product market competition - see Gilbert and Newbery 1982).

Most prominent explanations for the resistance of large incumbents to radical innovation focus on organizational abilities (or lack thereof), and why acquiring new ones is particularly challenging for the largest firms. The routines, filters, resources and capabilities that propelled a firm to succeed in the first place tend to become less valuable or even obsolete under radical innovation. Core competencies may become "core rigidities" during radical change (Leonard-Barton 1992). Firms focused on an existing customer base (Christensen 1997) or research trajectory (Tripsas and Gavetti 2000) may fail to even recognize their misalignment with a new technological reality. Or, they may find the effort of developing new knowledge, routines and resources too costly (Arrow 1974) or too risky (Hannan and Freeman 1984). Thus, the diffusion of radical innovation often comes at the expense of incumbent firms.

\subsection{Mixed Empirical Evidence}

While widely cited and conceptually compelling, the importance of distinguishing incremental innovations from radical ones has received limited empirical support. The extensive body of empirical work addressing the response of market leaders to new technological opportunities has been described as "notable for its inconclusiveness" (Cohen and Levin 1989). While more recent studies (e.g., Blundell et al. 1999) have made econometric advances, the literature has been criticized for failing to account for underlying industry heterogeneity and for confounding product and process innovation (Gilbert 2006).

Moreover, the fundamental distinction between incremental and radical types of innovation has yet to find broad-based empirical confirmation. Progress has been made, with meaningful differences established in single-industry settings such as food packaging (Ettlie et al. 1984), footwear manufacturing (Dewar and Dutton 1986), and the photolithographic alignment equipment industry (Henderson 1993). However, the incremental-radical distinction finds no support in the only multi-industry empirical work to consider the issue to date (Blundell et al. 1999). 
One reason for the lack of compelling cross-industry evidence may be the challenge that empirical researchers face in classifying innovative activity as either incremental or radical, ex ante, across a wide range of industry settings (i.e., without referring to the institutional details of a particular industry or product market). A key goal of this paper is to advance a framework for predicting how leading firms will react to technological innovations across a wide range of industry settings

\subsection{Product vs. Process Innovation}

A central challenge to this goal is the need to extend hypotheses found in the traditional literature into the novel setting of business processes. Existing research has focused overwhelmingly on the invention and commercialization of new products. Process innovation, in general, has received far less attention (Rosenberg 1982) - particularly in the scholarly literature. Business process innovation, has received even less, despite featuring prominently in firm investment and strategy over the past 20 years.

This class of innovative activity warrants more attention in light of theory and evidence that process innovation may differ in important ways from product innovation. Factors external to the firm such as product lifecycles (Utterback and Abernathy 1975), competitive pressure (Boone 2000) or customer requirements (Adner and Levinthal 2001) may emphasize one over the other in certain cases. Internal factors such as scale of output (Cohen and Klepper 1996, Klepper 1996) and organizational routines and priorities (Henderson et al. 1998) may also push firms along different innovation paths.

This sheds doubt on the extent to which we can automatically apply theory developed to describe product innovation to processes, and, in particular, to business processes. Works that specifically address incumbent response to process innovation tend to equate it with incremental change (e.g., Cohen and Klepper 1996, Klepper 1996, Boone 2000). Exceptions include Abernathy and Clark (1985), Tushman and Anderson (1986), Dewar and Dutton (1986), and Sull et al. (1997). However, they are largely based on industry-specific anecdotes and focus overwhelmingly on manufacturing processes.

\section{Theoretical Framework}

\subsection{Business Process Innovation Defined}

Business process innovation requires different knowledge and organizational skills from those demanded by product or manufacturing process innovation. Thus, it is important to be precise about what it entails - and what demands it makes of organizations.

The diffusion of the commercial internet in the 1990s created a new opportunity to transform and automate a wide variety of processes both within and between firms. The slogan of the business process reengineering movement was "Don't Automate, Obliterate!" (Hammer 1990), exhorting firms to exploit new technologies to create completely new business practices. Innovative ways of linking information and execution within operating processes held - and continue to hold - the potential to dramatically 
improve firm performance. Moreover, because business process innovation is difficult for competitors to observe, much less imitate, it offers the potential for generating sustainable competitive advantages.

The challenge, however, arises when novel operational knowledge is demanded in the transformation process and existing routines are replaced with unproven techniques. In particular, there is a parallel invention - or "co-invention" (Bresnahan and Greenstein 1996) - imperative that must be met. On the one hand, firms must develop or acquire the correct technology (primarily software) to support the new way(s) of doing business. On the other hand, adopters often must design new business processes and supporting organizational structures to conform to the technology's constraints. Because these interrelated demands can create misalignment between a firm's existing capabilities and those required to implement the new technology, adopters may be required to develop or acquire entirely new knowledge and skills to access the technological opportunities.

Even without dramatic process change, automation by itself can present significant organizational challenges. A primary benefit of automation is the guarantee that a particular process flow will be executed with speed and consistency for every related transaction. Through automation, innovative ideas can be diffused more rapidly throughout an entire organization with high fidelity, generating significant benefits (Brynjolfsson et al. 2008). However, because automation requires standardized operational practices and modalities of communication, it requires planning, communication, and negotiation amongst users to decide what those standards should be. Even relatively simple change often proves to be disruptive to existing routines and organizational structures, increasing pressure to "get it right the first time" and often generating internal conflicts and implementation delays (Edmondson et al. 2001).

\subsection{Classifying Business Process Innovations}

The challenges of business process innovation will tend to be exacerbated when the underlying business process is more complex, when it shares more interdependencies with other functions within the firm, and when it has a high impact on customers. Under these circumstances, the misalignment between old and new knowledge and capabilities is most likely to generate the types of organizational and economic risks that characterize radical innovation in more well-known settings (see Section 2).

\section{Complexity}

To begin, changes to more complex firm processes require more advanced organizational and procedural knowledge than do simpler adjustments. Intuitively, optimizing internal business processes and supporting technology for more complex routines and organizational structures demands more sophisticated operational know-how as well as more informational input from across the firm. As a result, more complex business process innovations require greater managerial skill and within-firm coordination. 
Empirically, prior research confirms that the costs of creating alignment between new information technology and the adopting organization through "co-invention" tend to be systematically higher wherever there are more complex processes involved (Bresnahan and Greenstein 1996).

\section{Interdependence}

The product innovation literature has noted the challenges that arise when interdependencies between product components, i.e., the "product architecture," are affected. This understanding of how components are linked becomes embedded in the structure of an organization, making changes to these linkages particularly destructive for established firms (Henderson and Clark 1990).

The analog in the business process setting is the set of activities that are operationally interdependent within the firm. Changes to a business process that is tightly coupled with others risks disrupting inter-process linkages, and, hence, the performance of the whole. As a result, changes to one process may require complementary innovation in other processes or other areas of the firm (Milgrom and Roberts 1990). This raises the stakes in terms of the amount of knowledge and coordination required to implement the change - as well as the likelihood and costs of failure. In the case of the new internetenabled process innovations, reductions in process times and other buffers such as work-in-process or finished goods inventory tend to further tighten the couplings among different operations, making change in one area even more risky overall (Brynjolfsson, Renshaw and Van Alstyne 1997).

\section{Impact on Customers}

Internal linkages are not the only challenge, however - external linkages matter, as well. A final dimension of this classification concerns the impact of the business process on customers. Managing change within an organization is sufficiently challenging when the primary stakeholders function within the boundaries of the same firm. In this case, hierarchy and shared culture will tend to facilitate both decision-making and the implementation of new interdependent processes. These advantages do not exist, however, when business processes cross firm boundaries. When essential firm activities require tight integration with other members of the value chain, the costs and risks associated with redesigning them increase dramatically. The greater the number or intensity of inter-firm linkages, the greater the difficulty of managing the business process change (Davenport 1993).

Taken together, differing degrees of complexity, interdependence, and impact on customers can usefully distinguish different business process innovations from each other in terms of the organizational and economic risk they entail. While perhaps not exhaustive, these criteria provide robust guidelines for placing a variety of business process innovations on the continuum between incremental and radical, facilitating clear predictions about how market leaders might respond to their introduction. 


\subsection{Predicting the Behavior of Market Leaders}

As detailed in Section 2, prior work suggests that large incumbents will enjoy distinct advantages in the case of incremental innovation - and the opposite when it comes to more radical advances. While this prior literature has focused primarily on the production of new technologies, certain core arguments apply quite naturally to the adoption of new technologies - particularly in the case of the large-scale or strategically sensitive business process innovation, where adoption of even "off-the-shelf" solutions typically entails significant co-invention of complementary activities within the firm, not to mention the coordination challenges involved in selection and implementation of the supporting IT infrastructure.

For instance, the same economies of scale that make fixed investments in R\&D profitable for the producers of innovations will likewise improve the returns to fixed investments in adoption and adaptation: e.g., researching and licensing new technologies, customizing solutions to match internal needs, investing in new organizational capabilities, user training, etc. These advantages will apply to both incremental and radical business process innovations, conditional on sufficient fixed investment up front.

However, a central argument of this paper is that some or all of the size advantages in business process innovation may be overwhelmed by the opportunity costs and organizational risks entailed by disrupting existing routines, within-firm linkages, and supply chain relationships. Because these organizational risks are, by definition, low for incremental innovation, it is straightforward to sign the expected relationship between firm size and incremental business process innovation:

\section{Hypothesis 1: Firms with larger market shares will be disproportionately more likely to adopt} incremental business process innovations, all else equal.

By contrast, in the case of radical innovation, the largest incumbents will have the greatest value at stake, have more-established operating procedures subject to disruption, and face higher internal and external coordination costs. For these reasons, the organizational risks will tend to overwhelm the economic benefits for larger firms and the economic benefits themselves may diminish as the costs of cannibalization and customer disruption increase (e.g., Arrow 1962). Thus:

Hypothesis 2: Firms with larger market shares will be systematically less likely to adopt radical business process innovations, all else equal.

Note that these predictions differ depending on the characteristics of the innovations themselves (incremental vs. radical), and the demands they make on large incumbent firms. However, it is useful to consider certain characteristics of the organizations themselves that may generate similar effects.

First consider organizational structure. While greater size and sheer organizational inertia tend to make procedural complexity a hurdle to radical innovation for larger firms, organizational or 
operational complexity will also tend to exacerbate the knowledge and coordination challenges involved. These types of complexity are easily confounded with firm size, because larger firms typically operate in more lines of business and are dispersed across more operating establishments (see Table 3). While this correlation does not change the core predictions outlined above, if complexity is truly a key criterion for making a business process innovation more challenging, then separate measures of organizational or operational complexity ought to have their own negative associations with the adoption of radical business process innovations:

\section{Hypothesis 2a: Organizational or operational complexity will be negatively correlated with the} adoption of radical business process innovations.

Similarly, the degree to which a firm engages in vertically or horizontally integrated production will influence the need for coordination amongst its various business processes (McElheran 2010). Again, while this is a somewhat bigger issue for larger firms (and hence possibly confounded with size), if interdependence makes a proposed change more radical, this effect should also manifest separately:

\section{Hypothesis 2b: Greater operational interdependence will be negatively correlated with the} adoption of radical business process innovations.

To the extent that these characteristics can be empirically disentangled from firm size or market share per se, it becomes possible not only to test the main hypotheses, but also to confirm two of the key mechanisms proposed in the framework. The rich data that make this possible is described in Section 5.

The third criterion in determining the "radicalness" of a business process innovation - customer impact - is more challenging to disentangle from size, per se. Ideally, one would be able to measure variation amongst firms in the "total customer impact" - defined as impact per customer multiplied by the number of customers. However, firms with the largest market shares have, by definition, more customers and/or more sales per customer than smaller rivals. Lacking data on the suppliers and customers of the subject firms, justification for this final element of the framework rests primarily on the qualitative analysis to follow.

\section{Phenomenon: E-Business}

The explosion of new business processes enabled by the diffusion of the commercial internet in the late 1990s offers a rich empirical setting with the needed variation in both innovations and firm characteristics to identify the effects of interest. For simplicity and ease of mapping the practical applications to the theoretical framework, I restrict my focus to the use of new internet-based technologies to conduct business-to-business (B2B) purchases and sales online: i.e., e-buying and e-selling. 
It is worth noting that, in addition to its usefulness for theory-testing, the setting is interesting in and of itself. IT adoption represents an economically significant and nuanced phenomenon that is incompletely characterized by common measures of investment. Firm investment in information process equipment and software rose from roughly $\$ 200$ billion in the early 1990 s to over $\$ 500$ billion in recent years (U.S. Bureau of Economic Analysis). Industry analysts and observers estimate that more than half of such investment has taken place in "process-enabling information technology" (McAfee 2003). However, aggregate measures of IT investment or even adoption data on particular platforms or applications gloss over important differences in the impacts of these general-purpose technologies on adopters. To fully grasp IT's influence on firms and corporate strategy, one needs to understand how it is actually adapted and implemented by firms in their core activities (Fichman and Kemerer 1999, Kahl 2007). An advantage of this study, therefore, is the opportunity to observe how new internet-based IT has been applied to important and well-specified business uses - offering a rare window into how businesses can leverage technology in difficult-to-observe ways that have meaningful repercussions for their operational performance and long-term competitive outcomes.

\subsection{E-Buying vs. E-Selling in the late 1990s: Incremental vs. Radical Innovation}

While internet-based e-buying and e-selling shared a common technology platform, they actually addressed fundamentally different business practices in the late 1990s. These differences (which have been ignored in most scholarly studies of e-business ${ }^{2}$ ), provide the essential variation needed to classify ebuying and e-selling as incremental or radical according to the framework described in Section 3.

It is important to note that, while the focus of this paper is on frontier e-business practices relying on the internet for their electronic platform, Electronic Data Interchange (EDI) has existed since the 1970s to allow businesses to exchange documents such as purchase orders and invoices. For firms that already had EDI, the internet presented both the opportunity and risk of redesigning existing firm-to-firm transactions. Because this legacy technology represents a potential substitute for the new internet-based practices, I address the potential impact of EDI in the empirical analysis (see Section 7).

\section{E-Buying}

Early e-buying applications were focused on enabling online procurement of maintenance, repair, and operations (MRO) goods such as lubricant, spare parts, office supplies, etc. - i.e., anything consumed in the production process not directly put into finished goods. This indirect procurement centers on spot transactions involving highly standardized goods and is distinct from the procurement of

\footnotetext{
${ }^{2}$ E-commerce has garnered increasing attention, particularly in the information systems literature (Straub et al. 2002, Zhu and Kraemer 2002). Yet there has been very little attention paid to heterogeneity in the technologies and business practices subsumed by labels such as "e-commerce" or "e-business". The unique exception I know of is Hollenstein and Woerter (2008), although their finding that e-buying and e-selling share the same drivers of adoption stands in sharp contrast to what I find in the United States three years prior to their sample timeframe.
} 
specialized materials and parts for direct use in production (appropriately termed direct procurement). While cost savings from electronic indirect procurement can be significant - upwards of $70 \%$ per purchase (AMR Research 1999a) - it is a self-contained activity for the typical manufacturing plant.

Direct procurement, on the other hand, tends to involve a much greater diversity of items with much greater impact on core production processes. This complexity and interdependency would surely place innovations to direct procurement closer to the radical end of the spectrum. At the time of the Census survey, however, software solutions for direct purchasing over the internet were not widely available. ${ }^{3}$ Thus, all observed internet e-buying at the time of the study entailed the much simpler indirect procurement process.

\section{E-Selling}

In sharp contrast to e-buying, early e-selling applications focused primarily on finished goods (e.g., computers, clothing, consumer packaged goods, etc.) for sale to distribution partners and end users. As a result, these solutions tended to be more varied and far more complicated to implement for nearly all firms - in short, they were highly complex. In particular, they required a great deal of tailoring to the idiosyncrasies of the adopting firm and its trading partners. According to one analyst report at the time: "What the projects lack in simplicity they make up for with diversity," (AMR Research 199b).

Therefore, the demands of innovating in the selling process presented potential adopters with two costly alternatives: replace existing core processes with standardized "off the shelf" functionality from mainstream vendors, or else invest heavily in customization or developing their own e-selling software based on their existing business process requirements. Because these processes often embody key aspects of what firms consider to be their competitive advantage, the majority chose a hybrid approach involving both a high level of customization of available products and some business process reengineering (AMR 1999 b) - i.e., a high level of "co-invention." A recurring theme among industry observers at the time was the significant cost in terms of time and money required to undertake the complex internal coordination and customization required to implement new e-selling processes. ${ }^{4}$

Another striking characteristic of e-selling is that the goods and services governed by the new electronic processes involve multiple locations and functions throughout the firm. The pressure to create and maintain a unified "online presence" requires that entire product families (often produced at separate

\footnotetext{
${ }^{3}$ At the time, Ariba, Commerce One and similar vendors of "procurement" applications had well-defined offerings for MRO procurement. Firms such as Mercado and QRS specialized in meeting the needs of retailers to manage the flow of finished goods and had begun to extend their offerings into manufacturing. But very little headway had been made in terms of offering a solution that could effectively manage direct procurement (AMR Research 1999b).

${ }^{4}$ Even the notable successes, such as the launch of milpro.com by tool-manufacturer Milacron, Inc., were strikingly expensive. The firm spent a dollar in customization and consulting for every dollar of the software license, involved more than 120 people from across the company, and required 10 months to launch (Schultz 1999, Teach 1999).
} 
plants within the firm) and related services need to be supported by one comprehensive website. The inability to move products online in a piecemeal fashion generates interdependencies among even the most autonomous units within a firm. In addition, e-selling interacts with strategically sensitive business functions focused on brand image and customer relationship management. This requires coordination with complementary business activities from many different areas of the company.

E-selling also significantly impacts customers and customer interactions. As part of the implementation process, a firm and its trading partners must collaborate on what the online sales process should look like, what types of data ought to be exchanged, and where control for certain activities will lie. Yet determining how transactions and process flows should operate as they cross the firm boundary opens up existing contracts for renegotiation and often proves to be a risky and challenging undertaking (Davenport 1993). Online sales also often replace some fraction of offline transactions - particularly in the early stages of adoption while firms explore how to conduct business over the internet with their existing customers (AMR 1999b). Channel conflict was cited as the number-one concern of firms considering online sales at the time (Gilbert and Bacheldor 2000). All of these costs tend to scale with the size of a firm's operations (Davenport 1993).

Thus, early e-buying innovations allowed firms to cut costs in a relatively straightforward way with little organizational or economic risk. E-selling, in contrast, represented a far more radical innovation according to the classification developed in Section 3. These critical qualitative differences between the two business process innovations are reflected in the descriptive statistics on e-buying and eselling adoption presented in the next section, where e-buying enjoyed a somewhat higher degree of diffusion. The empirical test of interest, however, is to see whether e-selling was differentially more problematic for market leaders than for smaller rivals, influencing not only the speed but the distribution of adoption in ways that have strategic implications. This is the focus of the remainder of the paper.

\section{Data}

\subsection{Business Uses of the Internet}

The dependent variables capturing the uses of new internet technology by firms come from the Computer Network Use Supplement (CNUS) included in the U.S. Census Bureau's 1999 Annual Survey of Manufactures. The approximately 35,000 plants in the sample accounted for more than $50 \%$ of manufacturing employment and output in the U.S. at the time. They belonged to more than 20,000 firms in 86 different manufacturing industries, providing data across a wide range of market contexts.

The CNUS contains detailed information on plant adoption of a variety of e-business practices and supporting technologies. In particular, plants identify whether or not they place or accept orders over 
a network and whether the primary network for doing so is the internet. Establishments that report online purchases primarily over the internet are coded as having adopted e-buying, similarly for e-selling. ${ }^{5}$

\section{Summary Statistics}

According to this snapshot, the diffusion of electronic business capabilities is broad: e-buying and e-selling takes place in every manufacturing subsector and along the entire size distribution. Yet it is not terribly deep: only $29 \%$ of plants are estimated to either place or accept orders over the internet (Table 1).

Table 1. Adoption of E-Buying and E-Selling in US Manufacturing, 1999

\begin{tabular}{|c|c|}
\hline $\begin{array}{l}\text { Internet-based E-business } \\
\text { Practice }\end{array}$ & $\begin{array}{c}\text { \% of Plants in Population } \\
\text { (estimated) }\end{array}$ \\
\hline E-buying & $21 \%$ \\
\hline E-selling & $15 \%$ \\
\hline E-buying or E-selling & $29 \%$ \\
\hline E-buying \& E-selling & $6 \%$ \\
\hline
\end{tabular}

These high-level summary statistics mask a great deal of heterogeneity in the use of internet technology. Industries vary significantly in the prevalence of e-commerce is (details available upon request). Computers \& Electronics and the Printing industry have the highest penetration. In the former, roughly $38 \%$ of plants place and $21 \%$ accept internet orders; in the latter, the percentages are $32 \%$ and $34 \%$ for buying and selling, respectively. Apparel is a trailing industry with just around $7 \%$ for both ebuying and e-selling. Some industries lean considerably more towards one e-business practice than the other. Only $6 \%$ of Textile Products plants place internet orders, but over $16 \%$ accept them.

Another important difference between e-buying and e-selling in the sample concerns the fact that the activities captured by the survey do not represent mirror images of the same transactions. The suppliers of MRO goods to manufacturing plants are not manufacturing firms themselves, but wholesale and retail outlets that sell a range of MRO products (e.g., Office Depot for paper and pens, Grainger for lubricants and batteries, etc.). Thus, the supplier-side of the e-buying transaction is not included in the manufacturing-based survey frame. Likewise, the distributors, wholesalers and retailers who typically make up the customer-side of the e-selling transaction also lie outside the manufacturing sector. (See Figure 1, which graphs the buying and selling transactions along the supply chain, with a rectangle

\footnotetext{
${ }^{5}$ A useful feature of this definition is that it excludes establishments that are merely experimenting with internetbased processes while still relying primarily on a different network (such as an intranet, extranet, or EDI) for its online transactions. This will reduce the likelihood of confounding borderline adoption or exploratory pilot projects with true business process innovation requiring substantial investment and co-invention by adopters.

${ }^{6}$ Estimates calculated using the Census Bureau's ASM sampling weights.
} 
framing the part of the chain sampled in the Census survey.). Thus, the e-buying and e-selling activities in this study concerned completely separate firm activities (though not necessarily independent investment decisions, which I address in the econometric model in the next section).

Figure 1. Differences between E-Buying and E-selling in the Census Survey

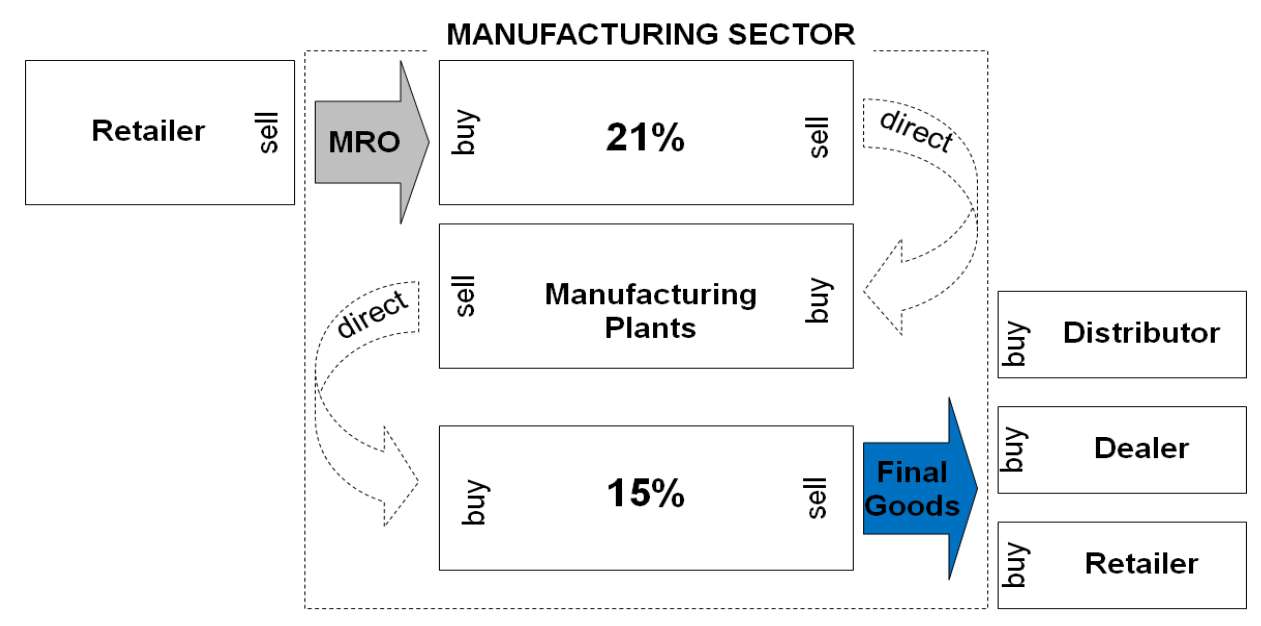

Solid arrows represent electronic transactions that were feasible between supply chain members at the time: ebuying of MRO goods and e-selling for final goods, as described in section 4. The empty arrows for direct goods signify the lack of commercially available direct procurement software solutions in the late 1990s. Direct procurement and sales took place in some fashion among manufacturing firms, but not using commercially available IT solutions. The frame around the manufacturing sector captures the fact that the survey does not cover the sellside of the MRO e-buying transaction or the buy-side of the final goods e-selling transaction. Due to these restrictions on electronic business solutions at the time and manufacturing-centric sample, e-buying and e-selling thus represented completely separate business processes in the CNUS survey.

\subsection{Market Leadership}

The main explanatory variable is market share of the adopting organization. I leverage the 1997 Census of Manufactures (CMF) ${ }^{7}$ to accurately measure the value of shipments in each industry ${ }^{8}$ and the share of that value shipped by each plant. I also calculate market share of the parent firm, defined for each plant as the percentage of country-wide value shipped from all plants belonging to the same firm to which the plant of interest belongs. To capture the underlying "quality" of the firm, I also calculate the relative total factor productivity of the establishment, assigning a dummy variable equal to one if it is in the top $20 \%$ of its NAICS 4 industry.

\subsection{Firm Characteristics Associated with Complexity and Interdependence}

Because the internal coordination challenge is likely to increase both with the number of distinct establishments and with the number of product lines produced throughout the firm, I take advantage of

\footnotetext{
${ }^{7}$ Conducted every five years by the US Census Bureau, this survey captures the value of all shipments from nearly all manufacturing plants in the country.

${ }^{8}$ I define the relevant market by the 4-digit NAICS code flagged as the primary product for each plant of interest. Note that all core results are robust to using a 6-digit NAICS industry definition controls (see Section 7).
} 
the 1997 CMF to construct measures for both of these. While the CMF does not capture nonmanufacturing establishments belonging to the parent firm, I proxy for coordination costs generated by geographic dispersion with the number of distinct manufacturing plants belonging to the parent firm. The coordination required by inter-product dependencies is captured using a count of the distinct product lines (at the 7-digit NAICS level) produced by the firm.

The $1997 \mathrm{CMF}$ also asks respondents to estimate the value of goods and services destined for other establishments within the same firm. I calculate the firm-wide value of these inter-plant transfers to estimate the economic value to the firm associated with this operationally interdependent production. Details and descriptive statistics for all variables are provided in Table 2.

\section{Empirical Model}

\subsection{Bivariate Probit Model of Adoption}

I employ a bivariate probit model of adoption to address the discrete nature of the adoption question on the survey and the possibility that the two choices are correlated (for instance by sharing hardware investments in servers and routers). Such a model assumes that a particular plant will adopt internet-based buying $(\mathrm{B})$ or selling $(\mathrm{S})$ if the net benefits $(N B)$ of doing so are greater than 0 . Thus, the probability of plant $i$ adopting electronic practice $j$ where $j \in B, S$ is captured by:

$$
\begin{gathered}
\left.\operatorname{Pr}\left(a_{i B}=1\right)=\operatorname{Pr} N B\left(M S_{i}, X_{i}\right)+\varepsilon_{i B}\right)>0 \text { and } \\
\left.\operatorname{Pr}\left(a_{i S}=1\right)=\operatorname{Pr} N B\left(M S_{i}, X_{i}\right)+\varepsilon_{i S}\right)>0
\end{gathered}
$$

where net benefits are expressed as a function of market share $\left(M S_{i}\right)$, a vector of other establishment, firm, and industry characteristics that influence e-commerce adoption $\left(X_{i}\right)$, as well as an unobserved error term that can be different for each technology $\left(\varepsilon_{i j}\right)$. Because establishments have the same observable characteristics for each equation, it is reasonable to worry that the unobservable characteristics might be also be correlated across the two technologies (i.e., $\operatorname{corr}\left(\varepsilon_{i E}, \varepsilon_{i S}\right) \neq 0$ ). Bivariate probit estimation has the desirable property of allowing for flexible correlation patterns between the error terms and explicitly testing whether they are correlated in the data. ${ }^{9}$

This treatment looks at whether or not adoption has taken place by a particular date and does not model the change in adoption status over time. The implicit behavioral assumption of such probit models

\footnotetext{
${ }^{9}$ Specifically, if $\left[\begin{array}{l}\varepsilon_{i E} \\ \varepsilon_{i S}\end{array}\right] \sim$ Bivariate Normal $\left(\left[\begin{array}{l}0 \\ 0\end{array}\right], \sigma^{2}\left(\begin{array}{cc}\mathrm{I} & \rho \mathrm{I} \\ \rho \mathrm{I} & \mathrm{I}\end{array}\right)\right)$, it estimates a coefficient for $\rho$.
} 
of adoption (David 1969) is that establishments with higher net benefits of adopting will adopt first and that non-adoption in the cross section captures relatively lower net benefit from adopting the technology.

\subsection{Identification}

The core of my research design is to examine the adoption behavior of the same firms at the same time to two innovations that are remarkably similar along many dimensions, but that vary in the specific ways that allow them to be classified as either incremental or radical business process innovations. The advantage of this approach is the ability to control for potentially confounding influences such as unobserved firm-specific "taste" for innovation. A given firm that is disproportionately likely to adopt any kind of new technology will bias the results towards adoption of both e-buying and e-selling. A technology laggard will have an equivalent negative effect on both technologies. Thus, it is the difference in leadership effects between the two technologies that identifies the effect of interest.

Statistically, identification in this model further requires that market share and other explanatory variables not be simultaneously determined with adoption. To mitigate this common concern (Gilbert 2006), I use lagged values of all explanatory variables to reduce simultaneity. Moreover, I include a rich set of controls for possible drivers of IT adoption that might confound the empirical results. For example, prior research finds strong correlations between IT adoption and the number of employees and firm age (Forman and Goldfarb 2006) as well as complementary skilled labor (Bresnahan et al. 2002). In addition, establishments belonging to multi-unit firms may have access to additional resources that could influence the investment decision (Forman et al. 2008). To address the possibility that decisions for establishments within the same firm may be correlated, all standard errors are clustered at the firm level. Unobserved effects arising from specific industry contexts are addressed by the inclusion of a rich set of industry dummies.

\section{Results}

\subsection{E-buying vs. E-selling}

Tables 4-6 report the average marginal effects of the bivariate probit analyses. They reveal a robust positive correlation between market leadership and e-buying, with an equally robust negative correlation between leadership and e-selling, supporting both of the main hypotheses. The appropriateness of the bivariate probit model is confirmed by a consistently significant coefficient on $\rho$, which captures the degree of correlation between the technology-plant-specific error terms.

\section{E-Buying}

According to the average marginal effects reported in Table 4, incumbents with greater logged market share were far more likely to purchase indirect goods and services over the internet. All else equal, 
an increase in a plant's share of the product market by one standard deviation is associated with a 3-6 percentage-point increase in the likelihood of adoption from the average rate of $21 \%$. At the mean, this represents an $18-27 \%$ increase in the likelihood of internet-based buying. ${ }^{10}$ Similar results (not shown) are found for alternative measures of market leadership such as sales and profits.

The top panel of Figure 2 illustrates how the effect in column $2 \mathrm{a}$ of Table 4 varies over the surface of market share values. ${ }^{11}$ It depicts a monotonic increase in the effect of market share, from a low of roughly one percentage point (or a $7 \%$ increase) to a high of over 9 percentage points (a $43 \%$ increase).

The specifications reported in columns $3 \mathrm{a}$ and $5 \mathrm{a}$ of Table 4 examine the effect of the parent firm's market position. The results are similar, though of somewhat smaller magnitude.

This pattern of results supports the hypothesis that there exist strong economies of scale in ebuying of indirect goods. Furthermore, it is consistent with the notion that the adjustment costs and risks associated with this incremental innovation were not disproportionately higher for the largest firms, giving them distinct advantages in adoption.

\section{E-Selling}

The opposite pattern emerges for e-selling. Average marginal effects presented in Table 4 indicate that a one-standard-deviation increase in a plant's market share is associated with a 2.2-3.5 percentage point decrease in the likelihood of e-selling. At the mean adoption of $14.6 \%$, this represents a $16-24 \%$ decrease in probability. A similar effect is seen for the market share of the plant's parent firm and other measures of market leadership (i.e., sales and profits - not shown).

The lower panel of Figure 2 shows the distribution of effects across the surface of logged market share for column $2 \mathrm{~b}$ in Table 4. Notably, as market share of the establishment increases, its negative impact on e-selling diminishes. This makes sense if economies of scale also apply in e-selling and actually start to overcome the effect of higher adjustment costs in determining the net benefits for the very largest firms. At the mean, however, the organizational costs and risks dominate these scale advantages.

\subsection{Omitted IT Capabilities}

As mentioned in Section 2, certain "competence-enhancing" innovations (Tushman and Anderson 1986), while requiring substantially new technical knowledge, may nevertheless successfully align with the existing competencies, capabilities, and assets of leading firms. This highlights the need for careful consideration of a firm's prior investments in related capabilities - particularly in the case of radical

\footnotetext{
${ }^{10}$ The magnitude of this effect is calculated by multiplying the average marginal effect by the estimated standard deviation of the variable and then dividing by the baseline adoption rate for the technology. For column 1a of Table 4 , this is $(.022 \mathrm{X} 1.75) / .21$, or $18 \%$.

${ }^{11}$ Arbitrary values are reported. The precise range of the variable is not approved for disclosure by the Census Bureau, as endpoints represent values for individual establishments in the sample.
} 
innovation. In the particular case of IT-based process innovations, one can think about implementations of other complex, large-scale IT applications as investments in an organization's co-invention capabilities. Prior research in information systems refers to this as "lowering the knowledge barrier" for IT adoption (Attewell 1992, Fichman and Kemerer 1997). A useful proxy for this is the presence of Enterprise Resource Planning (ERP) applications, which are notoriously difficult to implement due to their impact on a wide range of complex and interdependent business practices - and whose presence is believed to boost the return to investments in e-commerce applications (AMR 1999b).

An additional concern centers on the potentially confounding effects of electronic data interchange (EDI) adoption. If larger firms are more likely to have legacy EDI systems (for instance, due to economies of scale in adoption), and EDI substitutes for internet-based B2B transactions, a negative correlation between size and e-selling adoption could be spuriously generated by this relationship.

Table 5 presents the coefficients on dummy variables indicating whether the establishment reports having fully-integrated ERP or an EDI network in place. These are not ubiquitous technologies in 1999: only $15 \%$ of establishments report having ERP and roughly $14 \%$ have EDI. However, the impact of these other IT investments on e-buying adoption is significant. The presence of an ERP "backbone" at the establishment boosts the likelihood of e-buying adoption by nearly $23 \%$ (column 1a). EDI has a similar positive effect, suggesting that little indirect procurement was taking place over legacy EDI systems or that there were low or no switching costs. ${ }^{12}$

The impact of ERP on e-selling is a bit ambiguous. Column $1 \mathrm{~b}$ reports no effect, while column $3 \mathrm{~b}$ suggests that it might have a marginally positive impact (a $7 \%$ positive correlation at the $11 \%$ significance level). It is surprising that this effect is not greater, given analysts' emphasis of the role of ERP in enabling B2B transactions (e.g., AMR 1999b). One possible interpretation is that the internally-focused demands of ERP implementation are qualitatively different from the inter-firm coordination and coinvention challenges of e-selling, making ERP a poor enabler or "training ground" for innovation that spans firm boundaries.

The negative impact of EDI on e-selling, in contrast, is striking. This indicates that EDI-based selling represents a viable substitute with non-trivial switching costs for these B2B transactions. Column $2 \mathrm{~b}$ of Table 5 reports a greater than 5-point drop in the e-selling probability, representing a 38\% reduction. However, the effect of including the EDI variable on the estimated effect of plant market share is insignificant, leaving the core empirical findings intact.

Another potential source of bias would be other related firm capabilities that are not embodied in these prior IT investments. To address the possibility that leading firms might simply have stronger

\footnotetext{
${ }^{12}$ Interaction effects between market share variables and IT dummies are never significantly different from zero, likely due to the high positive correlation between market share and adoption of both ERP and EDI (not shown). This finding holds in the linear probability model, as well. Results available upon request.
} 
complementary capabilities, I control for total factor productivity at the plant. This should capture unobserved technology or managerial skill that may contribute to plant success while also influencing the e-business investment decision. Lack of significant results in Table 5 alleviates this concern.

\subsection{Heterogeneity in Use Matters}

The point estimates for both e-buying and e-selling are quite stable across a range of specifications, reinforcing the robustness of these findings. However, the results are not robust to certain definitions of the dependent variable. In particular, a naïve regression of market share on "e-commerce", defined as either e-buying or e-selling (or both) over the internet, shows no significant relationship between the logged market share of the plant and adoption (not shown). Thus, important differences in how firms actually use the internet for their business needs would have been completely obscured without careful treatment of the different demands of the two e-business innovations.

Also, even though this paper is focused on the internet-based e-buying and e-selling, the core results look very similar when the analysis is run for e-buying or e-selling over any network platform (results available upon request). These findings reinforce the notion that it is not the technology platform as much as the $u$ se of the technology that matters.

\subsection{Complexity}

Thus far, the results are consistent with the argument that e-selling constituted a radical innovation with disproportionate economic and organizational risks for leading firms. The theoretical framework emphasizes the role that business process complexity plays in driving this relationship. Support for this explanation is found in the coefficient on the multi-unit flag: belonging to a firm consisting of more than one plant reduces the likelihood of e-selling adoption by 2.3 to 3.7 percentage points, representing a 16-25\% decrease in the e-selling probability (Table 4). Further corroboration for Hypothesis $2 \mathrm{a}$ can be found in the coefficients on the $\log$ of the number of plants and on the number of products associated with the parent firm (columns $1 b$ and $2 b$ of Table 6 ). An increase in former by one standard deviation reduces the likelihood of e-selling by approximately $6 \%$. An equivalent increase in the latter reduces the e-selling likelihood by $4 \%$. Both of these results are robust to omitting the market share variable from the regression.

\subsection{Interdependence}

The robustness of the classification framework can also be found in the results on the degree of operational interdependence of a firm's productions. Establishments belonging to firms with a one standard-deviation greater value of inter-plant transfers have an $8 \%$ lower chance of adopting e-selling (column 3, Table 6). This is consistent with Hypothesis $2 \mathrm{~b}$. 


\subsection{Potentially Confounding Competitive Effects}

An alternative explanation that predicts a negative correlation between process innovation and market leadership with no reference to the alignment between firm capabilities and technology requirements rests on the "replacement effects" hypothesized in Arrow's (1962) seminal work. In this model, because market leaders enjoy higher rents from each unit of sales, they face a higher opportunity cost of innovating. Importantly, protection from competitive pressure is necessary for this result to hold in a dynamic setting (Gilbert and Newbery 1982).

Despite the inclusion of industry controls, it is conceivable that large potential adopters of eselling happen to be in markets with less competition, which would allow for these replacement effects (and hence, a lower likelihood of adoption) to manifest without the presence of the economic and organizational risks that are central to my hypotheses. To test for the possibility that this alternative explanation is driving the results, I follow Aghion et al. (2005), in approximating a Lerner index to capture the intensity of competition in the different product markets. ${ }^{13}$

The Lerner index is ideally price minus marginal cost over price. Because actual margins and product prices are unobserved even in the rich Census data, I approximate them with a measure of profits over sales. Specifically, I divide the difference between sales and production costs (materials and wages) by total sales and subtract from one: $1-\frac{\text { (sales- cost of materials-wages) }}{\text { sales }}$. A higher Lerner index is assumed to represent a greater level of produce market competition (and hence lower margins). To avoid bias caused by short-term market fluctuations or empirical outliers, I take the value-weighted average of this measure for each industry over the past 10 years, where industry defined by a 4-digit SIC code. ${ }^{14}$

The results in Table 7, however, contain no evidence that variation in competitive pressure is correlated with variation in the market share coefficient in the adoption regressions. The direct coefficient on the Lerner index is not significantly different from zero in column 1a, nor does the effect of the plant's market share vary across different values of the Lerner index. The point estimate for the market share coefficient is robust to inclusion of the Lerner index (columns $2 a$ and $2 b$ ). This "non-result" may be attributable to the identification challenges posed by trying to estimate the effect of product market competition while controlling for industry fixed effects (column 1a includes controls for the plant's 2digit SIC code). When industry dummies are removed from the model (columns $3 a \& 3 b$ ), the coefficient becomes significant (and, somewhat surprisingly, negative ${ }^{15}$ ), but the market-share coefficient loses its

\footnotetext{
${ }^{13}$ While concentration ratios or a Herfindahl index are more commonly used in empirical work, they have the disadvantage of being correlated by definition with market share.

${ }^{14}$ Census shifted from the SIC classification to NAICS for the first time in 1997, so SIC is used for consistency.

${ }^{15}$ This is contrary to prior empirical findings of a positive correlation between product market competition and innovation (e.g., Blundell et al. 1999).
} 
precision. A similar lack of variation associated with competitive effects is found when a traditional Herfindahl index or 4-firm concentration ratio are used instead (results not shown). Thus, it is difficult to believe that competitive effects provide a compelling alternative explanation for the empirical results.

\section{Discussion and Conclusion}

This goal of this paper has been to deepen our understanding of how alignment between the demands of new technologies and the capabilities of firms of different sizes influences the distribution of innovative activity within a market. A rich strategy and innovation theory literature has returned to this question time and again, but the scope of the theory has remained unclear and robust multi-industry empirical evidence has, to date, been difficult to acquire. This paper makes progress on both fronts.

On the theory side, it contributes a new conceptual framework that extends the literature into the understudied but important area of business process innovation and clarifies how existing notions of "incremental" vs. "radical" innovation may be applied to this class of innovations. A principal advantage of this framework is that it maps out the precise mechanisms by which larger firms might excel at incremental innovation yet falter in the face of radical change. While the core predictions are not new, making the behavioral linkages more explicit clarifies how and to what extent we can extrapolate the well-established intuition into this novel setting. In addition, the added precision supports empirical tests of the proposed behavioral mechanisms, reinforcing the value of the theoretical foundation.

The empirical contribution comes from applying this framework to an extraordinarily rich setting with data on specific uses of new internet technologies across a range of industries.

A careful side-by-side comparison of e-buying and e-selling adoption yields robust, multiindustry evidence consistent with the prediction that large firms will embrace incremental business process innovation but will face disproportionate risks and adjustment costs when the proposed change is more radical. Moreover, support for the behavioral mechanism detailed in the theoretical framework is also forthcoming from the data. The impact of complexity is seen in a negative relationship between eselling adoption and greater firm dispersion across distinct locations or product markets. The importance of interdependence is reflected in the effect that more-integrated production has in reducing the likelihood of e-selling. These findings reinforce the notion that a willingness or ability to pursue business process innovation depends on characteristics of both the innovation and the firm: it is the alignment between the two that ultimately determines overall adoption patterns.

Leveraging data collected by the U.S. Census Bureau overcomes many empirical challenges common to this type of investigation. Yet, certain drawbacks of the empirical setting must be acknowledged. While being both rich and expansive in terms of the number of observations and industry variation, it is limited to a single year of data. This prevents exploration into the precise timing of 
investment decisions. Moreover, the CNUS survey only reports on firm behavior during an early stage of commercial internet diffusion- leaving open the question of how these effects might evolve as technology becomes more mature and/or adoption becomes more widespread.

In general, innovative activity focused on improving business processes warrants further attention by both theorists and empirical scholars. The vast majority of prior strategy and innovation research has focused on product innovation, paying short shrift to the costly and important developments that take place "inside the black box" (Rosenberg 1982) of the firm to boost productivity and competitiveness during technological change. Understanding the competitive implications of these new technologies and how firms address them is a growing imperative in the wired economy.

This paper takes a step in meeting this need, shedding light on important strategic considerations for both adopters and producers of new business process technologies. On the adoption side, my findings indicate that, in cases where firms must coordinate complex and interdependent activities throughout a larger organization, across more establishments - particularly while impacting customer interactions, adoption will tend to take place primarily among smaller firms. These co-invention capabilities may be more challenging for large firms to develop; yet they represent an important competitive advantage as technology becomes increasingly integrated into the operating processes of firms. In addition, the interfirm coordination challenge looms large as businesses grow ever more dependent on the performance of their extended value chain. Smaller firms may enjoy new opportunities to leapfrog their larger competitors through business-to-business process innovation.

These findings also have important implications for producers of new technologies and for the direction of technological change. If the largest, most powerful adopters in a market resist certain types of technological innovations (i.e., radical ones), this may slow the ultimate diffusion of breakthrough discoveries and/or skew the incentives of producers towards more incremental advances. At the same time, the possibility that firms of different sizes might differentially adopt general purpose technologies (i.e., some may apply them to incremental changes, while some leverage them for radical advances) suggests that producers of technologies with high co-invention potential may find a more diverse and stable customer base for their products.

The findings presented here can only hint at some of the long-term competitive implications. Yet they offer a springboard for future research that may deepen our understanding of the role that alignment between different types of innovation and different firm capabilities play in competitive strategy and market outcomes during periods of technological change. 
Figure 2. Market Share Effects across the Variable Surface
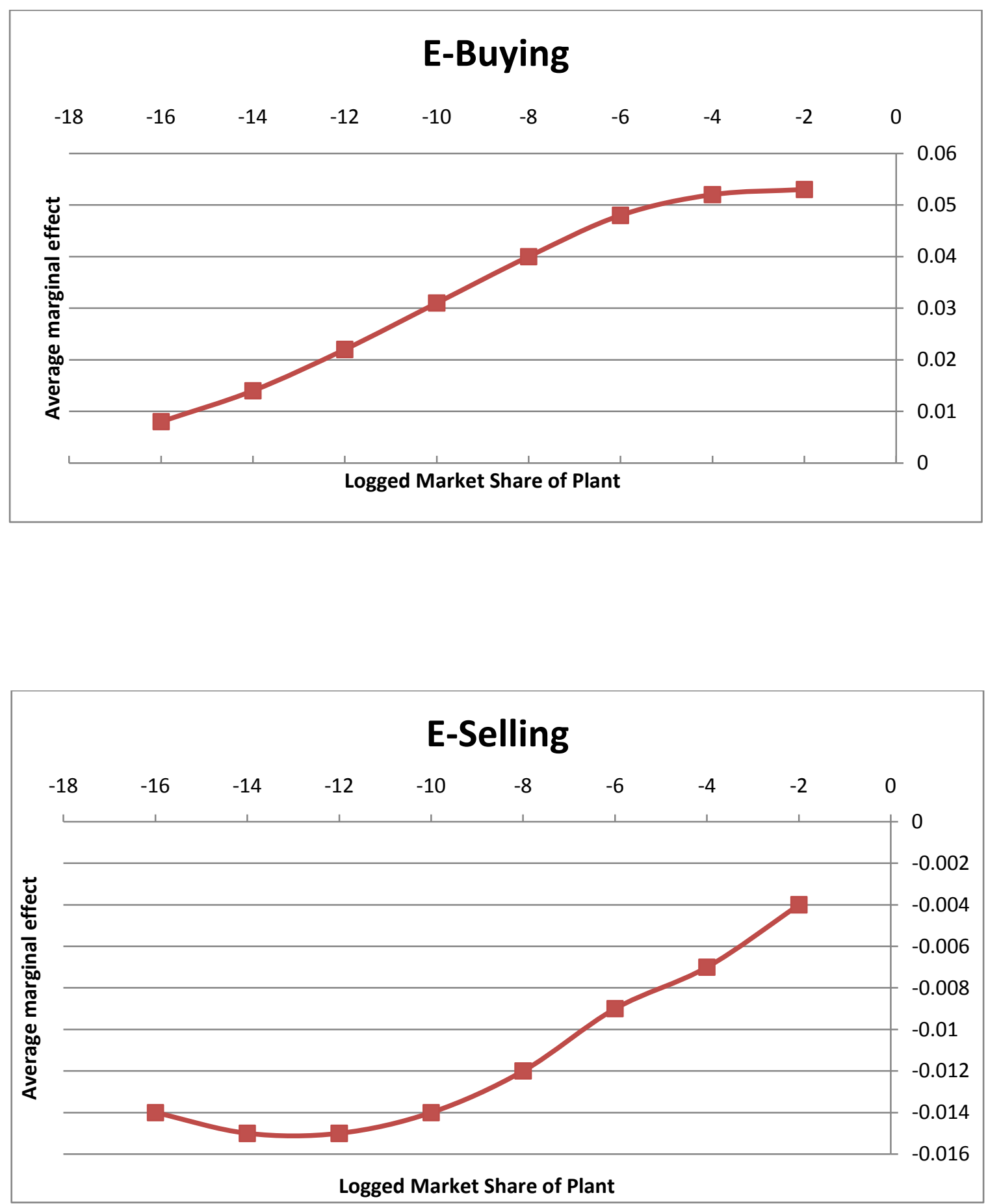
Table 2. Definitions, Means, and Standard Deviations of Variables

\begin{tabular}{|c|c|c|c|}
\hline Variable Name & Definition & Mean (est.) $\dagger$ & Std. Dev. (est.) \\
\hline E-BUY & $\begin{array}{l}=1 \text { if the plant reports buying primarily over the } \\
\text { internet; } 0 \text { else. }\end{array}$ & $\begin{array}{l}.213 \\
(.004)\end{array}$ & .410 \\
\hline E-SELL & $\begin{array}{l}=1 \text { if the plant reports selling primarily over the } \\
\text { internet; } 0 \text { else }\end{array}$ & $\begin{array}{l}.146 \\
(.004)\end{array}$ & .353 \\
\hline $\begin{array}{l}\text { PLANT_- } \\
\text { MKTSHARE }\end{array}$ & $\begin{array}{l}\text { Plant share of all product market sales in the U.S. } \\
\text { for its primary NAICS } 4 \text { code in } 1997\end{array}$ & $\begin{array}{c}.0004 \\
\left(7.34 \times 10^{-6}\right)\end{array}$ & .002 \\
\hline $\begin{array}{l}\text { LN_PLANT_ }_{-} \\
\text {MKTSHARE }\end{array}$ & Logged plant market share & $\begin{array}{l}-9.53 \\
(.019)\end{array}$ & 1.75 \\
\hline $\begin{array}{l}\text { FIRM_- } \\
\text { MKTSHARE }\end{array}$ & $\begin{array}{l}\text { Firm share of all product market sales in the U.S. } \\
\text { for its primary NAICS4 code in } 1997\end{array}$ & $\begin{array}{c}.003 \\
(.00005)\end{array}$ & .015 \\
\hline $\begin{array}{l}\text { LN_FIRM_- } \\
\text { MKTSHARE }\end{array}$ & Logged firm market share & $\begin{array}{l}-9.06 \\
(.023)\end{array}$ & 2.32 \\
\hline $\begin{array}{l}\text { MKTSHARE_ } \\
\text { GROWTH }\end{array}$ & $\begin{array}{l}\text { Change in plant share of SIC4 product market } \\
\text { from } 1992 \text { to } 1997\end{array}$ & $\begin{array}{c}.0001 \\
(.00002)\end{array}$ & .005 \\
\hline LN_EMP & Log of total employees at the plant in 1997 & $\begin{array}{c}3.51 \\
(.012)\end{array}$ & 1.22 \\
\hline LN_PROFIT & $\begin{array}{l}\text { Log of value-added minus salaries and wages in } \\
1997\end{array}$ & $\begin{array}{c}6.93 \\
(.019)\end{array}$ & 1.74 \\
\hline LN_SALES & Log of plant total revenues in 1997 & $\begin{array}{c}8.20 \\
(.017)\end{array}$ & 1.60 \\
\hline $\mathrm{AGE}<10$ & $=1$ if the plant is 10 or fewer years old; 0 else & $\begin{array}{l}.287 \\
(.005)\end{array}$ & .453 \\
\hline MULTI-UNIT & $\begin{array}{l}=1 \text { if plant is owned by a multiple-unit (i.e., multi- } \\
\text { plant) firm }\end{array}$ & $\begin{array}{c}.328 \\
(.004)\end{array}$ & .469 \\
\hline SKILLMIX & $\begin{array}{l}\text { Share of non-production worker wages to total } \\
\text { salaries and wages in } 1997\end{array}$ & $\begin{array}{l}.375 \\
(.002)\end{array}$ & .185 \\
\hline EDI & $\begin{array}{l}=1 \text { if plant has Electronic Data Interchange } \\
\text { technology }\end{array}$ & $\begin{array}{c}.139 \\
(.003)\end{array}$ & .355 \\
\hline ERP & $\begin{array}{l}=1 \text { if plant has a fully-integrated Enterprise } \\
\text { Resource Planning application }\end{array}$ & $\begin{array}{c}.152 \\
(.003)\end{array}$ & .359 \\
\hline LERNER & 1 minus the profit-to-sales ratio & $\begin{array}{l}.695 \\
(.007)\end{array}$ & .069 \\
\hline NUM PLANTS & $\begin{array}{l}\text { Number of manufacturing plants belonging to the } \\
\text { same parent firm in } 1997\end{array}$ & $\begin{array}{l}7.51 \\
(.106)\end{array}$ & 22.1 \\
\hline $\begin{array}{l}\text { LN- } \\
\text { NUMPLANT }\end{array}$ & $\begin{array}{l}\text { Log of the number of manufacturing plants } \\
\text { belonging to the same parent firm in } 1997\end{array}$ & $\begin{array}{c}.633 \\
(.008)\end{array}$ & 1.24 \\
\hline $\begin{array}{l}\text { \# FIRM } \\
\text { PRODUCTS }\end{array}$ & $\begin{array}{l}\text { Number of products (defined by NAICS7) } \\
\text { produced by plants belonging to the parent firm }\end{array}$ & $\begin{array}{c}5.6 \\
(.059)\end{array}$ & 12.8 \\
\hline $\begin{array}{l}\text { FIRM INTER- } \\
\text { PLANT } \\
\text { TRANSFERS }\end{array}$ & $\begin{array}{l}\text { Estimated value of goods and services shipped to } \\
\text { other establishments within the same firm }\end{array}$ & $\begin{array}{l}59.8 \mathrm{~K} \\
(2.4 \mathrm{~K})\end{array}$ & $790 \mathrm{~K}$ \\
\hline
\end{tabular}

$\uparrow$ Standard errors in parentheses. 
Table 3. Variable Correlations

\begin{tabular}{|c|c|c|c|c|c|c|c|c|c|c|c|c|c|}
\hline & $\begin{array}{c}\text { Plant } \\
\text { MS }\end{array}$ & $\begin{array}{l}\text { Firm } \\
\text { MS }\end{array}$ & $\begin{array}{c}\text { Logged } \\
\text { Employees }\end{array}$ & $\begin{array}{c}\text { Multi- } \\
\text { Unit }\end{array}$ & $\begin{array}{l}\text { Skill } \\
\text { Mix }\end{array}$ & Age $<10$ & $\begin{array}{c}\text { Logged } \\
\text { Sales }\end{array}$ & $\begin{array}{c}\text { Logged } \\
\text { Profit }\end{array}$ & $\begin{array}{c}\text { Top } \\
20 \% \\
\text { TFP } \\
\end{array}$ & $\begin{array}{l}\text { Num } \\
\text { Plants }\end{array}$ & $\begin{array}{c}\text { \# Firm } \\
\text { Products }\end{array}$ & $\begin{array}{l}\text { Firm } \\
\text { IPT }\end{array}$ & Lerner \\
\hline $\begin{array}{c}\text { Plant Market } \\
\text { Share }\end{array}$ & 1 & & & & & & & & & & & & \\
\hline $\begin{array}{c}\text { Firm Market } \\
\text { Share }\end{array}$ & .808 & 1 & & & & & & & & & & & \\
\hline $\begin{array}{c}\text { Logged } \\
\text { Employees }\end{array}$ & .770 & .604 & 1 & & & & & & & & & & \\
\hline $\begin{array}{l}\text { Multi-Unit } \\
\text { Flag }\end{array}$ & .491 & .677 & .441 & 1 & & & & & & & & & \\
\hline Skill Mix & -.084 & -.163 & -.074 & -.139 & 1 & & & & & & & & \\
\hline Age $<10$ & -.148 & -.090 & -.181 & -.048 & -.036 & 1 & & & & & & & \\
\hline $\begin{array}{l}\text { Logged } \\
\text { Sales }\end{array}$ & .878 & .761 & .861 & .551 & -.040 & -.161 & 1 & & & & & & \\
\hline $\begin{array}{l}\text { Logged } \\
\text { Profit }\end{array}$ & .805 & .696 & .789 & .512 & -.033 & -.142 & .919 & 1 & & & & & \\
\hline $\begin{array}{c}\text { Top 20\% } \\
\text { TFP }\end{array}$ & .053 & .061 & -.075 & .049 & -.063 & .041 & .053 & .215 & 1 & & & & \\
\hline Num Plants & .205 & .545 & .130 & .413 & -.136 & -.027 & .254 & .225 & .034 & 1 & & & \\
\hline $\begin{array}{l}\text { \# Firm } \\
\text { Products }\end{array}$ & .269 & .514 & .240 & .426 & -.108 & -.048 & .333 & .304 & .046 & .843 & 1 & & \\
\hline $\begin{array}{c}\text { Firm Inter- } \\
\text { Plant } \\
\text { Transfers }\end{array}$ & .163 & .230 & .194 & .116 & -.098 & -.024 & .225 & .190 & .024 & .260 & .272 & 1 & \\
\hline Lerner & .007 & -.008 & -.032 & -.050 & -.141 & .010 & -.023 & -.149 & -.008 & -.006 & -.013 & .053 & 1 \\
\hline
\end{tabular}


Table 4. Bivariate Probit Estimates: Market Share Effects in E-Business Adoption

\begin{tabular}{|c|c|c|c|c|c|c|c|c|c|c|}
\hline & $\begin{array}{c}\text { (1a) } \\
\text { E-Buy }\end{array}$ & $\begin{array}{c}\text { (1b) } \\
\text { E-Sell }\end{array}$ & $\begin{array}{c}\text { (2a) } \\
\text { E-Buy }\end{array}$ & $\begin{array}{c}(2 b) \\
\text { E-Sell }\end{array}$ & $\begin{array}{c}\text { (3a) } \\
\text { E-Buy }\end{array}$ & $\begin{array}{c}\text { (3b) } \\
\text { E-Sell }\end{array}$ & $\begin{array}{c}\text { (4a) } \\
\text { E-Buy }\end{array}$ & $\begin{array}{l}\text { (4b) } \\
\text { E-Sell }\end{array}$ & $\begin{array}{c}\text { (5a) } \\
\text { E-Buy }\end{array}$ & $\begin{array}{r}(5 \mathbf{b}) \\
\text { E-Sell }\end{array}$ \\
\hline $\begin{array}{l}\text { LN_PLANT_- } \\
\text { MKTSHARE }\end{array}$ & $\begin{array}{l}.020 \div * \% \\
(.002)\end{array}$ & $\begin{array}{l}-.020 \div \div \div \\
(.002)\end{array}$ & $\begin{array}{l}.033 \div \div \% \\
(.002)\end{array}$ & $\begin{array}{l}-.013 \div \div \div \\
(.002)\end{array}$ & & & $\begin{array}{l}.022 \div \div \% \\
(.005)\end{array}$ & $\begin{array}{l}-.016 \div \div \% \\
(.004)\end{array}$ & & \\
\hline $\begin{array}{l}\text { LN_FIRM_- } \\
\text { MKTSHARE }\end{array}$ & & & & & $\begin{array}{l}.021 * * * \\
(.002)\end{array}$ & $\begin{array}{l}-.012 * * * \\
(.002)\end{array}$ & & & $\begin{array}{l}.007 * * * \\
(.002)\end{array}$ & $\begin{array}{l}-.013 * \div \% \\
(.002)\end{array}$ \\
\hline LN_EMP & & & & & & & $\begin{array}{l}.016 * * \\
(.006)\end{array}$ & $\begin{array}{c}.004 \\
(.004) \\
\end{array}$ & $\begin{array}{l}.032 * * * \\
(.004)\end{array}$ & $\begin{array}{r}.0007 \\
(.003) \\
\end{array}$ \\
\hline MULTI-UNIT & & & $\begin{array}{c}.006 \\
(.008)\end{array}$ & $\begin{array}{l}-.037 * * * \\
(.006)\end{array}$ & $\begin{array}{l}-.001 \\
(.009)\end{array}$ & $\begin{array}{l}-.023 * * * \\
(.007)\end{array}$ & $\begin{array}{c}.005 \\
(.008)\end{array}$ & $\begin{array}{l}-.037 * * * \\
(.006)\end{array}$ & $\begin{array}{c}.002 \\
(.009)\end{array}$ & $\begin{array}{c}-.023 * * * \\
(.007)\end{array}$ \\
\hline $\mathrm{AGE}<10$ & & & $\begin{array}{l}.032 * * * \\
(.008)\end{array}$ & $\begin{array}{l}-.010 * \\
(.006)\end{array}$ & $\begin{array}{l}.025 * * * \\
(.008)\end{array}$ & $\begin{array}{l}-.009 \\
(.006)\end{array}$ & $\begin{array}{l}.034 * * * \\
(.008)\end{array}$ & $\begin{array}{l}-.010^{*} \\
(.006)\end{array}$ & $\begin{array}{l}.034 * * * \\
(.008)\end{array}$ & $\begin{array}{l}-.009 \\
(.006)\end{array}$ \\
\hline SKILLMIX & & & $\begin{array}{c}.024 \\
(.017)\end{array}$ & $\begin{array}{l}.025 * * \\
(.013)\end{array}$ & $\begin{array}{l}.037 * * \\
(.017)\end{array}$ & $\begin{array}{l}.020 \\
(.013)\end{array}$ & $\begin{array}{c}.026 \\
(.017)\end{array}$ & $\begin{array}{l}.026 * * \\
(.013)\end{array}$ & $\begin{array}{c}.033 * \\
(.017)\end{array}$ & $\begin{array}{c}.020 \\
(.013)\end{array}$ \\
\hline $\begin{array}{r}\text { Industry Controls } \\
\text { (86 NAICS4 } \\
\text { Dummies })\end{array}$ & \multicolumn{2}{|c|}{ No } & \multicolumn{2}{|c|}{ Yes } & \multicolumn{2}{|c|}{ Yes } & \multicolumn{2}{|c|}{ Yes } & \multicolumn{2}{|c|}{ Yes } \\
\hline $\bar{\rho}$ & \multicolumn{2}{|c|}{$\begin{array}{c}.428 \\
(.020)\end{array}$} & \multicolumn{2}{|c|}{$\begin{array}{c}.399 \\
(.020)\end{array}$} & \multicolumn{2}{|c|}{$\begin{array}{c}.399 \\
(.020)\end{array}$} & \multicolumn{2}{|c|}{$\begin{array}{c}.398 \\
(.020)\end{array}$} & \multicolumn{2}{|c|}{$\begin{array}{c}.397 \\
(.020)\end{array}$} \\
\hline $\mathrm{N}$ & \multicolumn{2}{|c|}{$\sim 35 \mathrm{~K}$} & \multicolumn{2}{|c|}{$\sim 35 \mathrm{~K}$} & \multicolumn{2}{|c|}{$\sim 35 \mathrm{~K}$} & \multicolumn{2}{|c|}{$\sim 35 \mathrm{~K}$} & \multicolumn{2}{|c|}{$\sim 35 \mathrm{~K}$} \\
\hline Wald $X^{2}$ & \multicolumn{2}{|c|}{198.62} & \multicolumn{2}{|c|}{4989.98} & \multicolumn{2}{|c|}{9317.15} & \multicolumn{2}{|c|}{5677.89} & \multicolumn{2}{|c|}{7967.69} \\
\hline Degrees of Freedom & \multicolumn{2}{|c|}{2} & \multicolumn{2}{|c|}{178} & \multicolumn{2}{|c|}{178} & \multicolumn{2}{|c|}{180} & \multicolumn{2}{|c|}{180} \\
\hline
\end{tabular}

Weighted maximum-likelihood bivariate probit estimation, reporting estimated average marginal effects for continuous variables and discrete change from 0 to 1 for dummy variables. Robust standard errors are clustered by firm and included in parentheses. Significance levels are denoted as follows: $* 10 \%, * * 5 \%, * * * 1 \%$. 
Table 5. Bivariate Probit Estimates

Effects of other Information Technology Investments Total Factor Productivity

\begin{tabular}{|c|c|c|c|c|c|c|c|c|}
\hline & $\begin{array}{l}\text { (1a) } \\
\text { E-Buy }\end{array}$ & $\begin{array}{c}(1 \mathrm{~b}) \\
\text { E-Sell }\end{array}$ & $\begin{array}{c}\text { (2a) } \\
\text { E-Buy }\end{array}$ & $\begin{array}{c}(2 b) \\
\text { E-Sell }\end{array}$ & $\begin{array}{c}\text { (3a) } \\
\text { E-Buy }\end{array}$ & $\begin{array}{c}(3 b) \\
\text { E-Sell }\end{array}$ & $\begin{array}{c}\text { (4a) } \\
\text { E-Buy }\end{array}$ & $\begin{array}{r}(4 a) \\
\text { E-Sell }\end{array}$ \\
\hline $\begin{array}{l}\text { LN_PLANT_ } \\
\text { MKTSHARE }\end{array}$ & $\begin{array}{l}.024 * * \% \\
(.005)\end{array}$ & $\begin{array}{l}-.016 * * * \\
(.004)\end{array}$ & $\begin{array}{l}.021 \div * \% \\
(.005)\end{array}$ & $\begin{array}{l}-.015 \div \% * \\
(.004)\end{array}$ & $\begin{array}{l}.023 * * \% \\
(.005)\end{array}$ & $\begin{array}{l}-.015 \div * * \\
(.004)\end{array}$ & $\begin{array}{l}.021 * * * \\
(.005)\end{array}$ & $\begin{array}{l}-.016^{* * *} \\
(.004)\end{array}$ \\
\hline LN_EMP & $\begin{array}{l}.011^{* *} \\
(.006)\end{array}$ & $\begin{array}{c}.006 \\
(.004)\end{array}$ & $\begin{array}{l}.013^{* *} \\
(.006)\end{array}$ & $\begin{array}{l}.007 * \\
(.004)\end{array}$ & $\begin{array}{c}.009 \\
(.006)\end{array}$ & $\begin{array}{l}.009 * * \\
(.004)\end{array}$ & $\begin{array}{l}.017 * * * \\
(.006)\end{array}$ & $\begin{array}{c}.004 \\
(.004)\end{array}$ \\
\hline ERP & $\begin{array}{c}.049 * * * \\
(.007)\end{array}$ & $\begin{array}{c}.003 \\
(.006)\end{array}$ & & & $\begin{array}{l}.045 * * * \\
(.007)\end{array}$ & $\begin{array}{c}.010 \dagger \\
(.006)\end{array}$ & & \\
\hline EDI & & & $\begin{array}{l}.047 * * * \\
(.007)\end{array}$ & $\begin{array}{l}-.055 * * * \\
(.007)\end{array}$ & $\begin{array}{l}.041 \% * * \\
(.008)\end{array}$ & $\begin{array}{c}-.057 * * * \\
(.007)\end{array}$ & & \\
\hline $\begin{array}{r}\text { Top 20\% } \\
\text { TFP }\end{array}$ & & & & & & & $\begin{array}{c}.005 \\
(.006)\end{array}$ & $\begin{array}{l}-.001 \\
(.005)\end{array}$ \\
\hline MULTI-UNIT & $\begin{array}{l}-.004 \\
(.007)\end{array}$ & $\begin{array}{l}-.033 * * * \\
(.006)\end{array}$ & $\begin{array}{c}.002 \\
(.008)\end{array}$ & $\begin{array}{c}-.033 * * * \\
(.006)\end{array}$ & $\begin{array}{l}-.006 \\
(.007)\end{array}$ & $\begin{array}{c}-.030 * * * \\
(.012)\end{array}$ & $\begin{array}{c}.005 \\
(.008)\end{array}$ & $\begin{array}{c}-.037 * * * \\
(.006)\end{array}$ \\
\hline $\mathrm{AGE}<10$ & $\begin{array}{c}.029 * * * \\
(.008)\end{array}$ & $\begin{array}{l}-.008 \\
(.006)\end{array}$ & $\begin{array}{l}.034 * * * \\
(.008)\end{array}$ & $\begin{array}{l}.009 \\
(.006)\end{array}$ & $\begin{array}{l}.029 * * * \\
(.008)\end{array}$ & $\begin{array}{l}-.008 \\
(.006)\end{array}$ & $\begin{array}{l}.034 * * * \\
(.008)\end{array}$ & $\begin{array}{l}-.010^{*} \\
(.006)\end{array}$ \\
\hline SKILLMIX & $\begin{array}{c}.013 \\
(.016)\end{array}$ & $\begin{array}{l}.031 * * * \\
(.012)\end{array}$ & $\begin{array}{c}.025 \\
(.017)\end{array}$ & $\begin{array}{l}.027^{* *} \\
(.013)\end{array}$ & $\begin{array}{c}.013 \\
(.016)\end{array}$ & $\begin{array}{l}.031 * * * \\
(.012)\end{array}$ & $\begin{array}{c}.028 \\
(.017)\end{array}$ & $\begin{array}{l}.025^{* *} \\
(.013)\end{array}$ \\
\hline $\begin{array}{l}\text { Industry } \\
\text { Controls }\end{array}$ & \multicolumn{2}{|c|}{$\begin{array}{c}\text { Yes } \\
\text { (NAICS4) }\end{array}$} & \multicolumn{2}{|c|}{$\begin{array}{c}\text { Yes } \\
\text { (NAICS4) }\end{array}$} & \multicolumn{2}{|c|}{$\begin{array}{c}\text { Yes } \\
\text { (NAICS4) }\end{array}$} & \multicolumn{2}{|c|}{$\begin{array}{c}\text { Yes } \\
\text { (NAICS4) }\end{array}$} \\
\hline $\bar{\rho}$ & \multicolumn{2}{|c|}{.404} & \multicolumn{2}{|c|}{.403} & \multicolumn{2}{|c|}{.409} & \multicolumn{2}{|c|}{.398} \\
\hline $\mathrm{N}$ & \multicolumn{2}{|c|}{$\sim 32 \mathrm{~K}$} & \multicolumn{2}{|c|}{$\sim 35 \mathrm{~K}$} & \multicolumn{2}{|c|}{$\sim 32 \mathrm{~K}$} & \multicolumn{2}{|c|}{$\sim 35 \mathrm{~K}$} \\
\hline Wald $X^{2}$ & \multicolumn{2}{|c|}{7662.33} & \multicolumn{2}{|c|}{3678.22} & \multicolumn{2}{|c|}{7671.27} & \multicolumn{2}{|c|}{5733.28} \\
\hline $\begin{array}{l}\text { Degrees of } \\
\text { Freedom }\end{array}$ & \multicolumn{2}{|c|}{182} & \multicolumn{2}{|c|}{182} & \multicolumn{2}{|c|}{184} & \multicolumn{2}{|c|}{182} \\
\hline
\end{tabular}

Weighted maximum-likelihood bivariate probit estimation, reporting estimated average marginal effects for continuous variables and discrete change from 0 to 1 for dummy variables. Robust standard errors are clustered by firm and are included in parentheses. Significance levels are denoted as follows: $\uparrow 11 \%, * 10 \%, * * 5 \%, * * * 1 \%$. The baseline adoption of ERP in the sample is $15.2 \%$ (estimated using sampling weights); EDI adoption is estimated at $13.9 \%$ of the overall sample. 
Table 6. Bivariate Probit Estimates: Organizational and Operational Complexity and Interdependence

\begin{tabular}{|c|c|c|c|c|c|c|}
\hline & $\begin{array}{c}\text { (1a) } \\
\text { E-Buy }\end{array}$ & $\begin{array}{c}(1 \mathrm{~b}) \\
\text { E-Sell }\end{array}$ & $\begin{array}{c}\text { (2a) } \\
\text { E-Buy }\end{array}$ & $\begin{array}{c}(2 b) \\
\text { E-Sell }\end{array}$ & $\begin{array}{c}\text { (3a) } \\
\text { E-Buy }\end{array}$ & $\begin{array}{l}(3 a) \\
\text { E-Sell }\end{array}$ \\
\hline $\begin{array}{l}\text { LN_PLANT } \\
\text { MKTSHARE }\end{array}$ & $\begin{array}{l}.023 * * * \\
(.005)\end{array}$ & $\begin{array}{l}-.015 * * * \\
(.004)\end{array}$ & $\begin{array}{l}.022 * * * \\
(.005)\end{array}$ & $\begin{array}{l}-.017 * * * \\
(.004)\end{array}$ & $\begin{array}{l}.023 * * * \\
(.005)\end{array}$ & $\begin{array}{l}-.016 * * * \\
(.004)\end{array}$ \\
\hline LN_EMP & $\begin{array}{l}.016 * * * \\
(.006)\end{array}$ & $\begin{array}{c}.003 \\
(.004)\end{array}$ & $\begin{array}{l}.016^{* * *} \\
(.006)\end{array}$ & $\begin{array}{c}.007 \\
(.004)\end{array}$ & $\begin{array}{l}.016 * * * \\
(.006)\end{array}$ & $\begin{array}{c}.004 \\
(.004)\end{array}$ \\
\hline LN_NUMPLANTS & $\begin{array}{c}.002 \\
(.002) \\
\end{array}$ & $\begin{array}{l}-.018 * * * \\
(.002)\end{array}$ & & & & \\
\hline $\begin{array}{r}\text { \# FIRM } \\
\text { PRODUCTS }\end{array}$ & & & $\begin{array}{c}.0001 \\
(.0002)\end{array}$ & $\begin{array}{l}-.0005 * * * \\
(.0001)\end{array}$ & & \\
\hline $\begin{array}{r}\text { FIRM INTER- } \\
\text { PLANT } \\
\text { TRANSFERS }\end{array}$ & & & & & $-2.25 \times 10^{-10}$ & $-1.50 \times 10^{-8 * *}$ \\
\hline MULTI-UNIT & & & $\begin{array}{c}.005 \\
(.008)\end{array}$ & $\begin{array}{l}-.036^{* * *} \\
(.006)\end{array}$ & $\begin{array}{l}.005 \\
(.008)\end{array}$ & $\begin{array}{l}-.036 * * * \\
(.006)\end{array}$ \\
\hline $\mathrm{AGE}<10$ & $\begin{array}{l}.035 * * * \\
(.008)\end{array}$ & $\begin{array}{l}-.010^{*} \\
(.006)\end{array}$ & $\begin{array}{l}.035^{* * *} \\
(.008)\end{array}$ & $\begin{array}{l}-.010^{*} \\
(.006)\end{array}$ & $\begin{array}{l}.035 * * * \\
(.008)\end{array}$ & $\begin{array}{l}-.010^{*} \\
(.006)\end{array}$ \\
\hline SKILLMIX & $\begin{array}{c}.025 \\
(.017)\end{array}$ & $\begin{array}{l}.021^{*} \\
(.013)\end{array}$ & $\begin{array}{r}.025 \\
(.018\end{array}$ & $\begin{array}{l}.024^{*} \\
(.013)\end{array}$ & $\begin{array}{c}.025 \\
(.017)\end{array}$ & $\begin{array}{l}.025^{* *} \\
(.013)\end{array}$ \\
\hline Industry Controls & \multicolumn{2}{|c|}{$\begin{array}{c}\text { Yes } \\
\text { (NAICS4) }\end{array}$} & \multicolumn{2}{|c|}{$\begin{array}{c}\text { Yes } \\
\text { (NAICS4) }\end{array}$} & \multicolumn{2}{|c|}{$\begin{array}{c}\text { Yes } \\
\text { (NAICS4) }\end{array}$} \\
\hline$\rho$ & \multicolumn{2}{|c|}{$\begin{array}{c}.397 \\
(.021)\end{array}$} & \multicolumn{2}{|c|}{$\begin{array}{c}.397 \\
(.021)\end{array}$} & \multicolumn{2}{|c|}{$\begin{array}{c}.397 \\
(.020)\end{array}$} \\
\hline $\mathrm{N}$ & \multicolumn{2}{|c|}{$\sim 35 \mathrm{~K}$} & \multicolumn{2}{|c|}{$\sim 33 \mathrm{~K}$} & \multicolumn{2}{|c|}{$\sim 35 \mathrm{~K}$} \\
\hline Wald $X^{2}$ & \multicolumn{2}{|c|}{7723.60} & \multicolumn{2}{|c|}{9191.79} & \multicolumn{2}{|c|}{5711.83} \\
\hline Degrees of Freedom & \multicolumn{2}{|c|}{180} & \multicolumn{2}{|c|}{182} & \multicolumn{2}{|c|}{182} \\
\hline
\end{tabular}

Weighted maximum-likelihood bivariate probit estimation, reporting estimated average marginal effects for continuous variables and discrete change from 0 to 1 for dummy variables. Robust standard errors are clustered by firm and are included in parentheses. Significance levels are denoted as follows: $\uparrow 11 \%$, $* 10 \%, * * 5 \%, * * * 1 \%$. 
Table 7. Competition Effects

\begin{tabular}{|c|c|c|c|c|c|c|c|c|}
\hline & \multicolumn{4}{|c|}{$\begin{array}{l}\text { Weighted Lerner index } \\
\text { including industry controls }\end{array}$} & \multicolumn{2}{|c|}{$\begin{array}{l}\text { Comparison model } \\
\text { excluding Lerner }\end{array}$} & \multicolumn{2}{|c|}{$\begin{array}{l}\text { Weighted Lerner } \\
\text { index (no industry } \\
\text { controls) }\end{array}$} \\
\hline & $\begin{array}{c}\text { (1a) } \\
\text { E-Buy }\end{array}$ & $\begin{array}{c}\text { Surface } \\
\text { detail }\end{array}$ & $\begin{array}{c}(1 b) \\
\text { E-Sell }\end{array}$ & $\begin{array}{c}\text { Surface } \\
\text { Detail }\end{array}$ & $\begin{array}{c}\text { (2a) } \\
\text { E-Buy }\end{array}$ & $\begin{array}{c}(2 \mathbf{b}) \\
\text { E-Sell }\end{array}$ & $\begin{array}{c}\text { (3a) } \\
\text { E-Buy }\end{array}$ & $\begin{array}{c}(3 b) \\
\text { E-Sell }\end{array}$ \\
\hline $\begin{array}{l}\text { LN_PLANT_- } \\
\text { MKTSHARE } \\
\text { (SIC4) }\end{array}$ & $\begin{array}{l}.010 * * * \\
(.003)\end{array}$ & & $\begin{array}{l}-.007 * * * \\
(.002)\end{array}$ & & $\begin{array}{l}.009^{* *} \\
(.003)\end{array}$ & $\begin{array}{l}-.006^{* * * *} \\
(.002)\end{array}$ & $\begin{array}{l}.0007 \\
(.003)\end{array}$ & $\begin{array}{l}-.012 * * * \\
(.002)\end{array}$ \\
\hline (a) Lerner $=0$ & & $\begin{array}{l}.009 * * * \\
(.003)\end{array}$ & & $\begin{array}{l}-.009 * * * \\
(.003)\end{array}$ & & & & \\
\hline (a) Lerner $=.25$ & & $\begin{array}{l}.009 * * * \\
(.003)\end{array}$ & & $\begin{array}{l}-.008 * * * \\
(.003)\end{array}$ & & & & \\
\hline (a) Lerner $=.5$ & & $\begin{array}{l}.010 * * * \\
(.003)\end{array}$ & & $\begin{array}{l}-.007 * * * \\
(.002)\end{array}$ & & & & \\
\hline (a) Lerner $=.75$ & & $\begin{array}{l}.010 * * * \\
(.003)\end{array}$ & & $\begin{array}{l}-.006 * * * \\
(.002)\end{array}$ & & & & \\
\hline (a) Lerner $=1$ & & $\begin{array}{l}.010 * * * \\
(.003)\end{array}$ & & $\begin{array}{l}-.006^{* * *} \\
(.002)\end{array}$ & & & & \\
\hline LERNER & $\begin{array}{c}.038 \\
(.048) \\
\end{array}$ & & $\begin{array}{l}.055 \\
(.033) \\
\end{array}$ & & & & $\begin{array}{l}-.082 * * \\
(.039)\end{array}$ & $\begin{array}{l}-.076 * * \\
(.033)\end{array}$ \\
\hline LN_EMP & $\begin{array}{c}.029 * * * \\
(.004)\end{array}$ & & $\begin{array}{l}-.005^{*} \\
(.003)\end{array}$ & & $\begin{array}{l}.029 * * * \\
(.004)\end{array}$ & $\begin{array}{l}-.005^{*} \\
(.003)\end{array}$ & $\begin{array}{c}.037 * * * \\
(.004)\end{array}$ & $\begin{array}{l}.002 \\
(.003)\end{array}$ \\
\hline MULTI-UNIT & $\begin{array}{c}.009 \\
(.007) \\
\end{array}$ & & $\begin{array}{l}-.041 * * * \\
(.006)\end{array}$ & & $\begin{array}{c}.009 \\
(.007)\end{array}$ & $\begin{array}{l}-.042 * * * \\
(.006)\end{array}$ & $\begin{array}{c}.011 \\
(.007)\end{array}$ & $\begin{array}{c}-.046 * * * \\
(.006)\end{array}$ \\
\hline $\mathrm{AGE}<10$ & $\begin{array}{c}.036^{* * *} \\
(.008)\end{array}$ & & $\begin{array}{l}.009 \\
(.006) \\
\end{array}$ & & $\begin{array}{l}.036^{* * *} \\
(.008)\end{array}$ & $\begin{array}{l}.009 \\
(.006)\end{array}$ & $\begin{array}{c}.033 * * * \\
(.008)\end{array}$ & $\begin{array}{l}-.008 \\
(.006)\end{array}$ \\
\hline SKILLMIX & $\begin{array}{l}.034 * * \\
(.017)\end{array}$ & & $\begin{array}{l}.035 * * * \\
(.012)\end{array}$ & & $\begin{array}{l}.034 * * \\
(.017)\end{array}$ & $\begin{array}{l}.035 * * * \\
(.012)\end{array}$ & $\begin{array}{l}.062 * * \\
(.016)\end{array}$ & $\begin{array}{l}.043 * * * \\
(.012)\end{array}$ \\
\hline Industry Controls & \multicolumn{4}{|c|}{ SIC2 } & \multicolumn{2}{|c|}{ SIC2 } & \multicolumn{2}{|c|}{ No } \\
\hline $\bar{\rho}$ & \multicolumn{4}{|c|}{$\begin{array}{c}.398 \\
(.021)\end{array}$} & \multicolumn{2}{|c|}{$\begin{array}{c}.398 \\
(.021)\end{array}$} & \multicolumn{2}{|c|}{$\begin{array}{c}.424 \\
(.024)\end{array}$} \\
\hline $\mathrm{N}$ & \multicolumn{4}{|c|}{$\sim 35 \mathrm{~K}$} & \multicolumn{2}{|c|}{$\sim 35 \mathrm{~K}$} & \multicolumn{2}{|c|}{$\sim 35 \mathrm{~K}$} \\
\hline Wald $X^{2}$ & \multicolumn{4}{|c|}{4241.89} & \multicolumn{2}{|c|}{5810.71} & \multicolumn{2}{|c|}{520.05} \\
\hline Deg. of Freedom & \multicolumn{4}{|c|}{50} & \multicolumn{2}{|c|}{48} & \multicolumn{2}{|c|}{12} \\
\hline
\end{tabular}

Weighted maximum-likelihood bivariate probit estimation, reporting estimated average marginal effects for continuous variables and discrete change from 0 to 1 for dummy variables. Details of how market share effects vary across the surface of the appropriate Lerner index (defined at the NAICS4 industry level) are reported at the following values: 0 , $.25, .5, .75$, and 1 . These values are arbitrary and may not even represent actual values in the data. They are provided for illustrative purposes only. Robust standard errors are clustered by firm and are included in parentheses. Significance levels are denoted as follows: $* 10 \%, * * 5 \%, * * * 1 \%$. 


\section{REFERENCES}

Abernathy, W. J. and K. B. Clark (1985). "Innovation: Mapping the Winds of Creative Destruction." Research Policy 14: 3-22.

Adner, R. and D. Levinthal (2001). "Demand Heterogeneity and Technology Evolution: Implications for Product and Process Innovation." Management Science 47(5): 611-628.

Aghion, P., N. Bloom, R. Blundell, R. Griffith and P. Howitt (2005). "Competition and Innovation: An Inverted U Relationship." Quarterly Journal of Economics 120(2): 701-728.

AMR Research (1999a). Parker, B. Internet Procurement - Low Risk, High Return.

AMR Research (1999b). Parker, B. An Overview of the Sell-Side E-Commerce Market.

Arora, A., A. Gambardella, L. Magazzini and F. Pammolli (2009). "A Breath of Fresh Air? Firm Type, Scale, Scope, and Selection Effects in Drug Development." Management Science 55(10): 16381653.

Arrow, K. (1974). The Limits of Organization. New York, Norton.

Arrow, K. J. (1962). Economic Welfare and the Allocation of Resources to Invention. The Rate and Direction of Economic Activity: Economic and Social Factors. U.-N. B. C. f. E. R. a. C. o. E. G. o. t. S. S. R. Council. Princeton, Princeton University Press.

Athey, S. and A. Schmutzler (2001). "Investment and Market Dominance." $\underline{\text { RAND Journal of Economics }}$ 32(1): 1-26.

Attewell, P. (1992). "Technological Diffusion and Organizational Learning: The Case of Business Computing." Organization Science 3(1): 1-19.

Baldwin, W. L. and J. T. Scott (1987). Market Structure and Technological Change. New York, Harwood Academic Publishers.

Barney, J. B. (1991). "Firm Resources and Sustained Competitive Advantage." Journal of Management 17(1): 99-120.

Blundell, R., R. Griffith and J. Van Reenen (1999). "Market Share, Market Value and Innovation in a Panel of British Manufacturing Firms." Review of Economic Studies 66(3): 529-554.

Boone, J. (2000). "Competitive Pressure: The Effects on Investments in Product and Process Innovation." RAND Journal of Economics 31(3): 549-569.

Bresnahan, T. F., E. Brynjolfsson and L. M. Hitt (2002). "Information Technology, Workplace Organization, and the Demand for Skilled Labor: Firm-Level Evidence." Quarterly Journal of Economics 117(1): 339-376.

Bresnahan, T. F. and S. Greenstein (1996). "Technical Progress and Co-Invention in Computing and in the Uses of Computers." Brookings Papers on Economic Activity. Microeconomics 1996: 1-83. 
Brynjolfsson, E., A. McAfee, M. Sorell and F. Zhu (2008). "Scale without Mass: Business Process Replication and Industry Dynamics." Harvard Business School Technology \& Operations Mgt. Unit Research Paper No. 07-016.

Brynjolfsson, E. and A. A. Renshaw (1997). "The Matrix of Change." Sloan Management Review 38(2): $37-54$.

Christensen, C. M. (1997). The Innovator's Dilemma. New York, Harper Collins.

Cohen, W. M. and S. Klepper (1996). "Firm Size and the Nature of Innovation within Industries: The Case of Process and Product R\&D." Review of Economics \& Statistics 78(2): 232-243.

Cohen, W. M. and R. C. Levin (1989). Empirical Studies of Innovation and Market Structure. Handbook of Industrial Organization. R. Schmalensee and R. D. Willig. New York, Elsevier. 2: 1059-1107.

Davenport, T. H. (1993). Process Innovation: Reengineering Work through Information Technology. Cambridge, MA, Harvard Business School Press.

David, P. A. (1969). A Contribution to the Theory of Diffusion. Memorandum No. 71. Stanford Center for Research in Economic Growth, Stanford University.

Dewar, R. D. and J. E. Dutton (1986). "The Adoption of Radical and Incremental Innovations: An Empirical Analysis." Management Science 32(11): 1422-1433.

Edmondson, A. C., R. M. Bohmer and G. Pisano (2001). "Disrupted Routines: Effects of Team Learning on New Technology Adaptation." Administrative Science Quarterly 46: 685-716.

Ettlie, J. E., W. P. Bridges and R. D. O'Keefe (1984). "Organization Strategy and Structural Differences for Radical versus Incremental Innovation." Management Science 30(6): 682-695.

Fichman, R. G. and C. F. Kemerer (1997). "The Assimilation of Software Process Innovations: An Organizational Learning Perspective." Management Science 43(10): 1345-1363.

Fichman, R. G. and C. F. Kemerer (1999). "The Illusory Diffusion of Innovation: An Examination of Assimilation Gaps." Information Systems Research 10(3): 255-275.

Forman, C. and A. Goldfarb (2006). ICT Diffusion to Businesses. Handbook of Economics and Information Systems. T. Henderschott, Elsevier. 1: 1-52.

Forman, C., A. Goldfarb and S. Greenstein (2008). "Understanding the Inputs into Innovation: Do Cities Substitute for Internal Firm Resources?" Journal of Economics and Management Strategy 17(2): 295-316.

Gatignon, H., M. L. Tushman, W. Smith and P. Anderson (2002). "A Structural Approach to Assessing Innovation: Construct Development of Innovation Locus, Type, and Characteristics." Management Science 48(9): 1103-1122.

Gilbert, A. and B. Bacheldor. (2000, May 27). "The Big Squeeze." Information Week, from http://www.informationweek.com/779/channel.htm. 
Gilbert, R. J. (2006). Looking for Mr. Schumpeter: Where Are We in the Competition-Innovation Debate? Innovation Policy and the Economy. A. B. Jaffe, J. Lerner and S. Stern. Cambridge, MIT Press. 6: 159-215.

Gilbert, R. J. and D. M. G. Newbery (1982). "Preemptive Patenting and the Persistence of Monopoly." American Economic Review 72(3): 514-526.

Hammer, M. (1990). "Reengineering Work: Don't Automate, Obliterate." Harvard Business Review 68(4): 104-112.

Hannan, M. T. and J. Freeman (1984). "Structural Inertia and Organizational Change." American Sociological Review 49(2): 149-164.

Henderson, R. (1993). "Underinvestment and Incompetence as Responses to Radical Innovation: Evidence from the Photolithographic Alignment Equipment Industry." RAND Journal of Economics 24(2).

Henderson, R. and K.B. Clark (1990). "Architectural Innovation: The Reconfiguring of Existing Product Technologies and the Failure of Established Firms." Administrative Science Quarterly 35(1): 930.

Henderson, R., J. del Alamo, T. Becker, J. Lawton, P. Moran and S. Shapiro (1998). "The Perils of Excellence: Barriers to Effective Process Improvement in Product-Driven Firms." Production and Operations Management 7(1).

Hollenstein, H. and M. Woerter (2008). "Inter- and Intra-Firm Diffusion of Technology: The Example of E-Commerce: An Analysis Based on Swiss Firm-Level Data." Research Policy 37(3): 545-564.

Kahl, S. J. (2007). "Utilizing Use: The Potential Impact of Customer Use Patterns on Technology and Industry Evolution." Academy of Management Best Paper Proceedings.

Kamien, M. I. and N. L. Schwartz (1982). Market Structure and Innovation. Cambridge, Cambridge University Press.

Klepper, S. (1996). "Entry, Exit, Growth and Innovation over the Product Life Cycle." American Economic Review 86(3): 562-583.

Leonard-Barton, D. (1992). "Core Capabilities and Core Rigidities: A Paradox in Managing New Product Development." Strategic Management Journal 13: 111-125.

McAfee, A. (2003). "When Too Much It Knowledge Is a Dangerous Thing." MIT Sloan Management Review 44(2): 83-89.

McElheran, K.S. (2010). "Delegation in Multi-Establishment Firms: The Organizational Structure of I.T. Purchasing Authority.” U.S. Census Bureau Center for Economic Studies Working Paper \#10-35.

Milgrom, P. and J. Roberts (1990). "The Economics of Modern Manufacturing: Technology, Strategy, and Organization." American Economic Review 80(3): 511-528. 
Nelson, R. R. and S. G. Winter (1982). An Evolutionary Theory of Economic Change. Cambridge, MA, Harvard University Press.

Reinganum, J. F. (1983). "Uncertain Innovation and the Persistence of Monopoly." American Economic Review 73(4): 741-748.

Rosenberg, N. (1982). Inside the Black Box. Cambridge, Cambridge University Press.

Schultz, B. (1999, May 4th, 2010). "Tooling Along Online: Metalworking Products Maker Milacron Wins Our Debut E-Com Innovator Award." Network World, from http://www.networkworld.com/ec/0222innovator.html.

Schumpeter, J. A. (1934). The Theory of Economic Development. Cambridge, Harvard University Press. Schumpeter, J. A. (1942). Capitalism, Socialism, and Democracy. New York, Harper.

Straub, D. W., D. L. Hoffman, B. W. Weber and C. Steinfield (2002). "Measuring E-Commerce in NetEnabled Organizations: An Introduction to the Special Issue." Information Systems Research 13(2): 115-124.

Sull, D. N., R. S. Tedlow and R. S. Rosenbloom (1997). "Managerial Commitments and Technological Change in the Us Tire Industry." Industrial and Corporate Change 6(2): 461-500.

Sutton, J. (1991). Sunk Costs and Market Structure. Cambridge, MA, MIT Press.

Teach, E. (1999). "Setting up Cybershop." CFO Magazine. 15(10), October 1:

Tripsas, M. (1997). "Unraveling the Process of Creative Destruction: Complementary Assets and Incumbent Survival in the Typesetter Industry." Strategic Management Journal 18(Summer Special Issue): 119-142.

Tripsas, M. and G. Gavetti (2000). "Capabilities, Cognition, and Inertia: Evidence from Digital Imaging." Strategic Management Journal 21(10-11): 1147-1161.

Tushman, M. L. and P. Anderson (1986). "Technological Discontinuities and Organizational Environments." Administrative Science Quarterly 31(3): 439-465.

U.S. Bureau of Economic Analysis (2009). National Income and Product Accounts. http://www.bea.gov. U.S. Department of Commerce (2000). E-Stats.

Utterback, J. M. and W. J. Abernathy (1975). "A Dynamic Model of Process and Product Innovation." Omega 3(6): 639-656.

Varon, E. (2001). "The ABCs of B2B." CIO.com. August 20.

Wernerfelt, B. (1984). "A Resource-Based View of the Firm." Strategic Management Journal 5(2): 171180.

Zhu, K. and K. L. Kraemer (2002). "E-Commerce Metrics for Net-Enhanced Organizations: Assessing the Value of E-Commerce to Firm Performance in the Manufacturing Sector." Information Systems Research 13(3): 275-295. 